\title{
MISSÃO DO DIREITO INTERNACIONAL NO MUNDO PÓS-MODERNO \\ -- REFLEXÃO PELOS 190 ANOS DO DIREITO INTERNACIONAL NAS \\ ARCADAS
}

\author{
MISSION OF INTERNATIONAL LAW IN THE POST-MODERN WORLD - REFLECTION FOR THE 190 \\ YEARS OF INTERNATIONAL LAW IN “ARCADAS”
}

Paulo Borba Casella*

\begin{abstract}
Resumo:
Desde o início, em março de 1828, o Direito Internacional tem sido ensinado, sem interrupção, na Faculdade de Direito de São Paulo, como então se chamava; mais do que nunca, o Direito Internacional tem papel a cumprir na formação dos profissionais do direito e na busca da inserção competitiva do Brasil.

Palavras-chave: Direito Internacional. Faculdade de Direito da Universidade de São Paulo, 190 anos. Ensino do Direito Internacional no Brasil.
\end{abstract}

\begin{abstract}
:
Since the beginning of the Law School in São Paulo, as then called, in March 1828, International Law has been taught without interruption; more than ever, International Law has a role to play in the legal education of the law professionals and the search for competitive insertion of Brazil.
\end{abstract}

Keywords: International Law. University of São Paulo Law School, 190 years. Teaching of International Law in Brazil.

1. "Desculpai-me, senhores, por eu assim ocupar a vossa atenção. O estado próspero e animador em que se acha a nossa Faculdade, as suas tradições gloriosas, a sincera admiração que tributo à ilustração dos nossos mestres e colegas, prendem-me de tal modo, que não podia deixar de fazer estas considerações." Observava o lente substituto, Dr. Joaquim Augusto de Camargo, na Memória histórica acadêmica de 1877, em 1º de março de $1878 .{ }^{1}$

As considerações que se seguem homenageiam a tradição de 190 anos do que se poderia denominar de 'escola paulista' de direito internacional, e do ensino do direito internacional no Brasil, na tradição emanada da casa. Isso se e na medida em

\footnotetext{
Professor Titular de Direito Internacional Público, atualmente chefe do Departamento de Direito Internacional e Comparado e Presidente da Comissão de Publicação da Revista da Faculdade de Direito da USP.

1 FACULDADE DE DIREITO DE S. PAULO. Memória histórica acadêmica de 1877. São Paulo: [s.n.], 1878. p. 2. (catálogo da Biblioteca Central da Faculdade de Direito da USP. 378.4: 34(816.1) (091) RC F378.4 F128m e.7 S.E. tombo 09/87).
} 
que possa fazer sentido pretender circunscrever o direito internacional, seja temporal seja territorialmente.

O que, aliás, constitui perigo a ser evitado, como mostra a história do direito das gentes, depois do surgimento e desenvolvimento, nos séculos XVI e XVII, pautados pelo universalismo, ante a mudança de foco e de método que neste ocorre, entre o final do século XVIII e o início do XIX, trazendo-o para âmbitos e 'escolas' nacionais, como marcado pelo positivismo.

2. Aqui se põe a reflexão sobre o que possa ser essa tradição paulista em direito, e especificamente em relação ao direito internacional, em belo conjunto de cursos de graduação e pós-graduação. ${ }^{2}$ Ao fazê-lo, aqui hoje, por ocasião dos 190 anos da fundação dos cursos jurídicos, neste ano de $2017,{ }^{3}$ cabe transcender o plano pessoal, para ver a interação deste, com algo mais amplo e duradouro: o plano institucional, onde se considere $^{4}$ também a visão de como desempenhar o esforço e a missão de ser professor de direito do Largo de São Francisco, de levar adiante, e manter a nossa tradição jurídica de excelência, especificamente no direito internacional.

Até o momento presente. Paradoxalmente, neste momento em que a internacionalização se mostra de maneira irreversível, mais do que nunca necessário o estudo desta, e a missão do direito internacional no mundo pós-moderno é que se deu a mudança da grade curricular, para que o programa de direito internacional público extenso e complexo como é - tenha de ser ministrado somente em um semestre!

3. Na escolha do tema, a presente reflexão dialoga com a anterior sobre o 'direito internacional nas Arcadas - a aula inaugural de 2009' ${ }^{5}$ Não se tratava então, como não se trata, depois de dez anos como professor titular (desde 2007, e doze do exercício das funções, desde 2005), somente de reflexão pessoal sobre o papel do docente, mas, simultaneamente, sobre a importância que pode ter este, focado na internacionalidade, no tempo presente - queiramos ou não, estamos insertos no contexto da pós-modernidade - e

2 VIDIGAL, Allan. Faculdade de Direito do Largo de São Francisco: USP 190 anos. Prefácio de José Rogério Cruz e Tucci. São Paulo: DBA., 2017.

3 No seminário pelos 190 anos da Faculdade de Direito da USP, de 14 a 18 de agosto de 2017, diversos temas do direito internacional, público e privado, do direito do comércio internacional e arbitragem, como da cooperação internacional e da proteção internacional de minorias foram apresentados em sucessivas mesas, ao longo de toda a quinta-feira, 17 de agosto.

4 Também responder à expectativa da comunidade - que nos financia, com parcela dos impostos do estado de São Paulo.

5 A aula inaugural sobre o Direito Internacional nas Arcadas reunia dois dados vitais centrais: o direito internacional e a vida da casa, que comecei a frequentar ao ingressar na Faculdade de direito do Largo de São Francisco, em 1978! Lá me graduei, em 1982, lá me doutorei em direito internacional, em 1986, lá fiz a minha livre docência em direito internacional, em 1993, lá concorri duas vezes, e conquistei, em 2007, a titularidade em direito internacional público. Magistério desde então exercido. Ver CASELLA, Paulo Borba. Direito internacional nas arcadas: a aula inaugural de 16 de fevereiro de 2009. Revista da Faculdade de Direito da Universidade de São Paulo, São Paulo, v. 104, p. 931-966, jan./dez. 2009. 
neste contexto, no qual nos encontramos, ao lado da tradição, cabe perquirir o papel de cada um, no sentido de manter e desenvolver, em nossa escola, o estudo e o ensino do 'direito eclesiástico, diplomático e das gentes', como primeiro se chamou a cadeira de direito internacional público.

Ao suceder aos mestres que, desde 1828, ininterruptamente, a ocuparam é o papel, que me cabe desempenhar, na regência da prestigiosa cátedra de direito internacional público. Levar adiante, no tempo útil desta geração, essa missão, bem como, alternadamente, exercer a chefia do Departamento de direito internacional e comparado.

4. A história desta escola se liga à história do país, e isso de vários modos: quantas das questões aqui suscitadas tiveram e tem impacto sobre o que em âmbito nacional se enfrentaria - já foi, muitas vezes, dito, e ouvir-se-á outras vezes - e isto se dá não somente no passado. ${ }^{6}$

A identidade nacional se fez concomitantemente ao funcionamento desta escola, à formação de sistema jurídico nacional, e de tradição, ao mesmo tempo, legal e humanista, desta escola, nesta escola, e, a partir dela, repercute para o estado, para o país, e forçosamente, também para o plano internacional. ${ }^{7}$ E se transforma, se adapta e se renova. ${ }^{8}$ E continua a ser a referência, para o bem e para o mal, neste país, em matéria de ensino jurídico.

5. Para a formação do Brasil independente teve-se o cuidado de prover duas Academias de direito, na qual pudessem formar-se os quadros de gestão nacional - de modo a não mais ser inexorável deslocar-se para Coimbra ou alhures, para a formação não somente profissional, como intelectual e de vida. Façam-se as críticas que se fizerem, dentre os elementos para tal formação, desde o início do funcionamento das

${ }_{6} \quad$ A criação de cursos superiores quando se instaura um país, como se deu no então recém-instaurado império brasileiro, não negligenciou o papel destes, para a formação não somente de quadros de gestão - como se desejava e se declara desde o início, e evitar que se mantivesse a subordinação intelectual - e mais do que isso, em relação à célula-mãe, a Faculdade de Direito de Coimbra. Também se exprime essa criação como dado de formação e de afirmação de identidade nacional, que então se esboçava.

7 O professor Irineu Strenger costumava dizer que um professor de direito internacional não pode olhar somente para o quintal de casa! Ver CASELLA, Paulo Borba. Direito internacional, vida e memória de Irineu Strenger (1923-2007). Revista de Arbitragem e Mediação, São Paulo, v. 4, n. 15, p. 11-18, out./dez. 2007.

8 CASELLA, Paulo Borba. Fundamentos do direito internacional pós-moderno. São Paulo: Quartier Latin, 2008, esp. item XIII, 'boa tradição e a que se deve evitar'; CASELLA, Paulo Borba. Abz: ensaios didáticos. Prefácio de João Grandino Rodas. São Paulo: Imprensa Oficial do Estado, 2008, cap. 'Faculdade enquanto possibilidade - o papel do Largo de São Francisco', p. 79-98, cit. p. 79): “A análise do legado da tradição serve para evidenciar valores e critérios de condução da prática estatal externa do Brasil independente: quando esta é boa, pode dar bons frutos; quando não o for, ao menos poderá ser, no futuro, evitada, para que não se repitam os erros Desde cedo, no plano internacional, defende a igualdade jurídica dos estados e a solução pacífica de controvérsias. Poderiam estes ser dados relevantes, para a política externa e a atuação internacional do Brasil, perfeitamente consentâneos com o direito internacional pós-moderno e as exigências de inserção mundial em contexto cada vez mais competitivo." 
duas academias (como se deu, a partir de março de 1828, para a de São Paulo, e maio do mesmo ano, para a de Olinda) determinou-se o ensino e o estudo do direito das gentes! Esse ensinamento nunca se interrompeu no largo de São Francisco, ${ }^{9}$ diversamente do que, nessa mesma época, chega a ocorrer em universidades estrangeiras.

$\mathrm{O}$ ensino do direito das gentes, ${ }^{10}$ como então se chamava, se punha desde o primeiro ano. E nunca se interrompeu. O curso de São Paulo foi instalado em março de 1828 e o de Olinda em maio do mesmo ano. Por isso, se diz ter sido a nossa a primeira, porquanto a instituição irmã pernambucana somente dois meses depois começou a operar. ${ }^{11}$

6. Muito nos interessa ter sido, em nossa escola, a aula inaugural do curso jurídico a lição de direito das gentes, ministrada em março de $1828,{ }^{12}$ por José Maria Avelar Brotero, ${ }^{13}$ "lente do primeiro anno do curso jurídico de São Paulo". Nasce o ensino da casa paulista com vocação internacional, e o seu primeiro titular foi o primeiro professor de direito brasileiro. ${ }^{14}$

Tanto mais surpreendente parecerá contrapor-se-lhe a supressão da obrigatoriedade deste, e a inserção do direito internacional público ou privado como uma dentre várias disciplinas optativas, no regime federal do currículo mínimo, para os cursos de direito, tal como vigeu de 1972 até 1994 !

10 Comentava SOARES, Guido Fernando Silva. Curso de direito internacional público. São Paulo: Atlas, 2002. v. 1. p. 15-16. "Desde então, a disciplina jamais saiu dos currículos universitários dos estudantes do Largo de São Francisco, sempre como matéria obrigatória, mesmo quando passou a denominar-se, como na atualidade Direito internacional público. Foram responsáveis por seu ensino brilhantes publicistas, que se destacaram no Brasil e no exterior, como seu primeiro catedrático: o Conselheiro Brotero (Avelar Brotero), ao qual se seguiram os mestres: Amaral Gurgel, Ferreira França, Oliveira Coutinho, João (sic, José) Mendes, Brás Arruda e Vicente Marotta Rangel, este, na atualidade, eminente Juiz do Tribunal Internacional do direito do mar, sediado em Hamburgo, e renomado especialista em direito do mar. Não menos brilhantes foram os alunos que estudaram e que dedicaram parte de suas vidas ao Direito internacional público e que passaram para a história como ilustres brasileiros e destacados defensores do Brasil, em foros internacionais. Para citar somente alguns do final do século XIX e início do século XX: o Visconde de Ouro Preto, o Barão do Rio Branco e Rui Barbosa". Detalhava, a seguir, a evolução posterior do ensino do direito internacional.

11 As duas "Academias de direito", como então se chamavam, em 1854, passam a denominar-se "Faculdades de direito", e o curso de Olinda foi transferido para o Recife. Em 1869 foi implantada a reforma do ensino livre, segundo a qual o aluno não era obrigado a frequentar as aulas, mas apenas a prestar os exames e obter aprovação.

12 NOGUEIRA, José Luís de Almeida. A academia de São Paulo: tradições e reminiscências: estudantes, estudantões, estudantadas: edição comemorativa do sesquicentenário dos cursos jurídicos no Brasil, 18271977. 3. ed. São Paulo: Saraiva, 1977. v. 1, p. 34-35, 54, 58-59, 62-66, 230; v. 2, p. 21, 90-91, 110, 127, $175-$ 176, 194, 213-217, 228-231, 238-239, 244, 259-265, 283, 302, 315; v. 3, p. 24, 66, 89, 117; VIOTTI, Dario Abranches. O Conselheiro Brotero. Brasília, DF: Thesaurus, 1998. (Coleção Itiquira), antes publicado O Conselheiro José Maria de Avelar Brotero. Revista da Faculdade de Direito da Universidade de São Paulo, São Paulo, v. 69, n. 2, p. 255-272, jan./dez. 1974.

13 Pensem na história da casa, na próxima vez em que passarem pela Rua Conselheiro Brotero ou pelo Largo do Arouche! Vivia o professor Brotero às turras com o primeiro diretor da casa, José Arouche de Toledo Rendon, que várias vezes escreve ao Imperador, pedindo que o remova do cargo, "antes que venha ter às vias de fato com este senhor" - Dom Pedro condecora o diretor, e este permanecerá no cargo, até 1833.

14 Foi o primeiro titular da cátedra o Dr. José Maria de Avelar Brotero. O Conselheiro Brotero professor desta casa, foi o primeiro professor de direito do país, nomeado pelo Imperador, quem proferiu a lição inaugural desta Faculdade, em março de 1828. Regeu este a nossa cadeira, alternando-a com o (também) Conselheiro Dr. Manoel Joaquim do Amaral Gurgel. 
Entenda-se não ser isso pouco, se compararmos, na mesma altura, muitas universidades estrangeiras, inclusive europeias, simplesmente, não contavam, ou haviam interrompido, muitas somente retomarão, mais tarde, o funcionamento de cadeiras permanentes de direito internacional.

7. $\mathrm{O}$ direito das gentes, cujas origens remontam à Antiguidade, ${ }^{15}$ nos séculos XVI, XVII e XVIII se pauta por ter vocação universal, ${ }^{16}$ e segue presente, ao mesmo tempo, como fundamento de valor, de caráter absoluto, somado ao exame da prática.

A relação entre o direito internacional, como sistema teórico, e a observância deste, na prática, ${ }^{17}$ será tema recorrente, em tantas épocas e autores. Assim se faz a conjugação entre o dado criativo, onde se vão buscar as ideias capazes de reger as relações internacionais, e o dado que A. Verdross (1929) $)^{18}$ denomina reconstrutivo, porquanto supõe a existência de prática internacional, e cujo fim é o de analisar as regras por esta aplicadas.

8. Em tempos de mutação de conceitos e de revisão de heranças, recebidas de outras eras, característica da pós-modernidade, justamente cabe apontar lição: a mudança de foco, ocorrida no direito internacional, entre a segunda metade do século XIX e a primeira metade do século XX. Quando o direito internacional, vigente àquele tempo, comete a vergonha de acomodar a empreitada colonialista, acolhida e regulada pela normativa vigente, ${ }^{19} \mathrm{em}$ relação ao que fora o direito internacional dos séculos anteriores.

Este direito internacional da época se faz o arauto e o caminho para a expressão dos interesses nacionais - e, nessa exata medida e proporção, deixa de ser 'internacional', e perde a sua dimensão de universalidade. ${ }^{20}$ Esta lição é presente e continua atual e necessária.

15 CASELlA, Paulo Borba. Direito internacional no tempo antigo. São Paulo: Atlas, 2012.

16 CASELlA, Paulo Borba. Direito internacional no tempo do Iluminismo (no prelo, 2017); Direito internacional no tempo clássico. São Paulo: Atlas, 2015; Direito internacional no tempo moderno de Suarez a Grócio. São Paulo: Atlas, 2014; Direito internacional no tempo medieval e moderno até Vitoria. São Paulo: Atlas, 2012.

17 CASElla, Paulo Borba. Direito internacional dos espaços. São Paulo: Atlas, 2009.

18 VERDROSS, Alfred. Règles générales du droit international de la paix. Recueil des Cours de l'Académie de Droit International, Leinden/Boston, v. 30, p. 271-518, 1929. p. 276-277.

19 CHARVIN, Robert. Le droit international tel qu'il a été enseigné. Notes critiques de lecture des traités et des manuels (1850-1950). In: Le droit des peuples à disposer d'eux-mêmes: méthodes d'analyse du droit international. Mélanges offerts à Charles Chaumont. Paris: Pedone, 1984. p. 135-159; CHAUMONT, Charles. Cours général de droit international public. Recueil des Cours de l'Académie de Droit International, Leinden/Boston, v. 129, p. 333-528, 1970. cit. p. 345: «Si le droit classique est en voie de disparition comme phase historique, il n'est pas aboli comme méthode et vision».

20 KOSKENNIEMI, Martti. The gentle civilizer of nations: the rise and fall of international law 1870-1960. Cambridge: Cambridge University Press, 2005. p. 270-271: "One striking aspect of French international law towards the end of nineteenth century was its ability to connect a cosmopolitan outlook with an impeccably patriotic alignment behind French interests". 
9. Ocorreu primeiro o direito internacional, dito moderno e depois o direito internacional dito clássico, ligado, lógica e inexoravelmente, como toda obra humana, às condições e ao contexto do seu tempo. Mas, cumpre notar que este direito internacional tivera vocação e perfil verdadeiramente internacionais, em seus heroicos tempos, com os chamados pais do direito internacional moderno, nos séculos XVI, desde Francisco de Vitória e Francisco Suárez, ${ }^{21}$ até o direito internacional clássico e o direito internacional no tempo do iluminismo, no fim do século XVIII e início do XIX. ${ }^{22}$

Primitivo, ou incipiente, sob determinados aspectos, mas continha valores de universalidade, que merecem ser apontados e preservados. Essa busca de valores comuns, como base fundadora do sistema, é lição a ser lembrada. E que se retoma, buscando bases conceituais mais amplas para o direito internacional, no contexto pós-moderno. ${ }^{23}$

10. A seguir, no curso do século XIX e primeira metade do XX, terá lugar a que se poderia assim chamar 'nacionalização' do direito internacional, nessas diferentes tradições nacionais, ou tradição 'eurocêntrica' do direito internacional. ${ }^{24}$ Não menor foi o perigo de se pretender colocar o direito internacional como espécie normativa à parte, classe isolada no campo jurídico, como ainda pretendeu a doutrina dualista, ${ }^{25}$ a essa mesma época dominante.

Estas correntes que tantas concepções nacionais influenciou, se põem como referência, a partir da qual emergirá a que pode ser chamada de 'nossa' tradição,

${ }_{21}$ CASELLA, Paulo Borba. Direito internacional no tempo medieval e moderno até Vitoria. São Paulo: Atlas, 2012; CASELLA, Paulo Borba. Direito internacional no tempo moderno de Suarez a Grócio. São Paulo: Atlas, 2014; v. tb. ACCIOLY, Hildebrando Pompeo Pinto; SILVA, Geraldo Eulálio do Nascimento e; CASELLA, Paulo Borba. Manual de direito internacional público. 23. ed. São Paulo: Saraiva, 2017.

22 CASEllA, Paulo Borba. Direito internacional no tempo clássico. São Paulo: Atlas, 2015; CASELLA, Paulo Borba. Direito internacional no tempo do Iluminismo (no prelo, 2017).

23 ONUMA, Yasuaki. Direito internacional em perspectiva transcivilizacional: questionamento da estrutura cognitiva predominante no emergente mundo multipolar e multicivilizacional do século XXI. Tradução Alan Carvalho et al., org. da tradução e apresentação de Masato Ninomiya e Paulo Borba Casella. Belo Horizonte: Arraes Editores, 2017; ver tb. o recente volume de ONUMA Yasuaki. Le droit international et le Japon: une vision transcivilisationnelle du monde. Préface de Mireille Delmas-Marty. Paris: Pedone, 2016.

24 LAGHMANI, Slim. Histoire du droit des gens: du jus gentium impérial au jus publicum europaeum. Paris: Pedone, 2003.

25 Tal como a sustentam e desenvolvem na Alemanha TRIEPEL, Hermann. Les rapports entre le droit international et le droit international. Recueil des Cours de l'Académie de Droit International, Leinden/ Boston, v. 1, p. 73-122, 1923; nos EUA Moore com seu Digest of international law. Washington: Government Priting Office, 1860. 8 v., na Itália ANZILOTTI, Dionisio. Cours de droit international. Traduction Française par Gilbert Gidel. Paris: LGDJ, 1999; (1912 e 1929, na trad. para o francês de Gilbert GIDEL, avant propos de Pierre-Marie Dupuy e Charles Leben); CAVAGLIERI, Arigo. Règles générales du droit de la paix. Recueil des Cours de l'Académie de Droit International, Leinden/Boston, v. 26, p. 311-586, 1929; também Perassi e F. Capotorti em seu curso geral na Haia, CAPOTORTI, Francesco. Cours général de droit international public. Recueil des Cours de l'Académie de Droit International, Leinden/Boston, v. 248, p. 9-344, 1994, ainda pretende argumentar a "superioridade evidente da concepção dualista". Entre nós dãose, esporadicamente, recorrências do que certo integrante da mais alta corte do país denominou, em certa ocasião, denominou sermos país alinhado por pouco clara concepção de suposto "dualismo moderado". 
em direito internacional. Positivismo e dualismo são dois perigos a serem conhecidos e, assim, controlados, para que possa existir e operar o direito internacional.

11. O perigo maior consistiu no fato de que o direito internacional a partir do momento em que se contenta em descrever o direito positivo, se descola de sua base de valores, e perde, com o deslocamento desta, a sua própria vocação universalista, que tinha encontrado seu fundamento, precisamente na ideia de justiça universal, mesmo quando se busque ver esta aplicada às relações internacionais. $\mathrm{O}$ desaparecimento da base de valor, como ordenadora do sistema internacional, leva à substituição do fundamento do direito internacional, que passa a ser a expressão da vontade (Willenstheorie), seja de um ou de vários estados.

Essa concepção na falta de outro, busca o fundamento do direito internacional na vontade do(s) estado(s), incorre em intransigente dogmatismo, ao afirmar, sem dar provas, que o estado não pode estar vinculado, se não por meio de sua vontade, seja esta isolada ou conjuntamente manifestada, bem como incide em petição de princípios, porquanto qualquer obrigação internacional de um estado pressupõe a existência de norma superior, que se impõe à vontade deste. E seus maus frutos são sobejamente conhecidos. ${ }^{26}$

Felizmente renasce a busca dos valores, que deverão informar a formação e o funcionamento do sistema institucional e normativo internacional. São sintomas característicos da pós-modernidade: o direito internacional em tempos de humildade, e de revisão de suas premissas, para ensejar atuação consentânea com as necessidades do mundo presente, mas sem se deixar levar pelos imperativos do momento. ${ }^{27}$ Há que se buscar na teoria do convencimento jurídico (Rechtsüberzeugungstheorie) a base do direito internacional pós-moderno, sobretudo quando se trata do direito costumeiro. ${ }^{28}$

26 Até encontrar expressão caricatural na conduta da política externa da era G. W. Bush (2000-2008). Felizmente terminada esta fase sombria, ficou terrível herança para ser gerenciada, dentro e fora de casa, pelo sucessor, B. Obama (2009-2017). Ainda mais sombria se afigura a fase atual, sob a caricata e nefasta presidência de D. Trump (a partir de janeiro de 2017). Inquietantemente esclarecedora a comparação entre o uso sistemático da mentira nos discursos de D. Trump - como fazia Adolf Hitler - aponta SNYDER. Timothy. Sobre a tirania: vinte lições do século XX para o presente. São Paulo: Companhia das Letras, 2017, (do original On Tyranny: twenty lessons from the twentieth century, (C) 2017, trad. Donaldson M. Garshagen, 'Seja patriota', p. 107-110: “A democracia entrou em colapso na Europa nas décadas de 1920, 1930 e 1940, e está desmoronando atualmente não só em grande parte da Europa como também em muitas partes do mundo. É essa história e essa experiência que nos revelam o lado sombrio de nossos futuros possíveis. Um nacionalista dirá que ‘isso não pode acontecer aqui', o que é o primeiro passo para o desastre. Um patriota afirma que isso pode acontecer aqui, mas que vamos impedir isso."

27 Como se veem, também entre nós, nos seguidores de enfoque dito 'realista', sobretudo nas assim chamadas relações internacionais, pautando as análises pelo jogo de poder, destituídas de qualquer outro fundamento. E estas pretendem ser as vozes mais atuais! Somente deixa de ser direito internacional, ao ser desse modo tratado.

28 Apesar do perigo, apontado por HEILBORN, Paul. Les sources du droit international. Recueil des Cours de l'Académie de Droit International, Leiden/Boston, v. 11, p. 1-64, 1926. p. 22, no sentido de que uma norma de direito consuetudinário somente obrigaria os estados onde se pudesse configurar uso continuado 
12. Se, de um lado, andamos bem e tivemos o ensino do direito internacional desde literalmente o primeiro dia de funcionamento dos cursos jurídicos no Brasil, e isso mesmo antes de muitas universidades estrangeiras, à mesma época, por outro lado, nem sempre andamos bem desde então. Podem ser apontados alinhamentos no sentido de 'nacionalização' do direito internacional, no sentido de alinhamentos prioritários, por interesses nacionais e momentâneos. ${ }^{29}$

Tais desvios de rumo e traições de propósitos privam o direito internacional de sua dimensão verdadeira, tautologicamente internacional, como de seu conteúdo humano, que é indispensável manter, como foco e centro de todo sistema jurídico: o reconhecimento do ser humano como sujeito de direito, no plano internacional - reconhecido como sujeito de direitos, mediante a proteção internacional dos direitos fundamentais, como também sujeito de obrigações, no mesmo plano, pelo direito internacional penal.

13. Esses males devem ser apontados, por não ser somente desvio de rumo do passado, mas perigos recorrentes, contra o espírito e o propósito da disciplina. Pouco nos há de alegrar, ademais, o fato de que o ensino do direito internacional, nos cursos jurídicos do Brasil, ${ }^{30}$ ter sido relegado a posto secundário e 'optativo', no currículo mínimo dos cursos de direito, ${ }^{31}$ durante a assim chamada "flexibilização", ocorrida no período de 1972 a $1994 .{ }^{32}$ Ainda se colhem os (maus) frutos dessa escolha equivocada.

e proveniente da consciência jurídica (usage continuel et provenant d'une conscience juridique). Dentre autores que não exigirão, para a criação de norma de direito internacional geral a adesão de todos os estados, bastando provar que a prática geral seja a esta favorável, lembrem-se Westlake, Oppenheim, De Visscher, Fauchille, S. Romano, B. Pallieri. No mesmo sentido VERDROSS, Alfred. Règles générales du droit international de la paix. Recueil des Cours de l'Académie de Droit International, Leinden/Boston, v. 30, p. 271-518, 1929. p. 295 e 296, observa "en cas de différend entre deux états, sur l'existence d'une certaine règle coutumière, les tribunaux arbitraux compétents n'ont jamais examiné si une pareille règle a été reconnue précisément par les parties en litige, mais uniquement si elle a été acceptée en général par la pratique internationale. " (...) "Il nous suffit donc de constater que, d'après la conviction de la pratique internationale, les états ne sont pas seulement obligés par les règles coutumières à la formation desquelles ils ont participé, mais par toutes les coutumes acceptés par la pratique générale, non contredite, comme étant le droit".

29 Concomitantemente a políticas e movimentos sociais do tempo: “o petróleo é nosso!", “a Amazônia é nossa", "o mar territorial de 200 milhas" (sic), as restrições à importação de automóveis, a "política nacional de informática", as recorrentes diatribes contra a livre iniciativa, o capital internacional, "fora FMI", etc.

30 RODRIGUES, Horácio Wanderlei. Novo currículo mínimo dos cursos jurídicos. São Paulo: Revista dos Tribunais, 1995, esp. cap. 1, 'ensino jurídico no Brasil: balanço geral', p. 9-39, contém breve relato histórico.

31 RODRIGUES, Horácio Wanderlei. Novo currículo mínimo dos cursos jurídicos. São Paulo: Revista dos Tribunais, 1995, cap. 2, 'o currículo e suas reformas, na história do ensino jurídico brasileiro', p. 40-61. Nos anos de 1972 a 1994, boa parte dos cursos de graduação em direito, seguindo a diretriz da Resolução n. 3/72/ CFE, de 25 de fevereiro de 1972, emanada do Conselho federal de educação, manteve o direito internacional público ou direito internacional privado, como duas escolhas possíveis, dentre leque das matérias optativas.

32 Resolução n. 3/72/CFE: O presidente do Conselho Federal de Educação, no uso de suas atribuições legais, na forma do art. 26, da Lei n. 5.540, de 28 de novembro de 1968, e tendo em vista o parecer 162/72 (...) resolve: art. $1^{\circ}$. O currículo mínimo do curso de graduação em direito compreenderá as seguintes matérias: (...) 1 a 11 (...) 12/13. "Duas dentre as seguintes: (a) direito internacional público, (b) direito internacional privado, (c) 
Até ser substituída pela Portaria n. 1.886/94/MEC, ${ }^{33}$ que instaura o regime aplicável, a partir de 1994, quando retorna à obrigatoriedade o ensino do direito internacional nos cursos jurídicos nacionais. ${ }^{34}$

Foram necessários mais de vinte anos, praticamente o espaço de vida útil de uma geração, para voltar o direito internacional a ser parte do currículo mínimo 'obrigatório': descobriram os burocratas universitários a importância deste? E a falta que faz para a formação do bacharel em direito, no mundo globalizado? Antes tarde do que nunca, se terá descoberto esta evidência.

14. Consigne-se nunca se ter interrompido o ensino do direito internacional na casa, ${ }^{35}$ mesmo durante o período da ditadura militar e da nefasta "flexibilização do currículo mínimo obrigatório". Diversamente do que ocorreu em muitas faculdades de direito brasileiras, naquele tempo.

Ora, parece, fazemos o movimento inverso: não se reduz a carga horária do direito internacional público, na graduação, mas em lugar de ser esta disciplina ministrada em dois semestres, com duas horas de aula semanais, será ensinada em somente um semestre, com carga horária de quatro aulas semanais. $\mathrm{O}$ que reduz pela metade o tempo de absorção de conteúdos básicos e de maturação dos conceitos, indispensáveis para a formação dos alunos.

15. O direito internacional não pode ser visto nem tratado como disciplina puramente técnica: não tem caráter somente instrumental e não pode ser reduzido a isso. Tem dimensão intelectual e humana, a ser preservada, para que possa cumprir a sua missão precípua de construir bases para a comunicação e o diálogo entre os homens, como entre os colegiados humanos, sejam estes os estados, as organizações internacionais e os demais agentes do contexto internacional presente.

ciência das finanças e direito financeiro (tributário e fiscal), (d) direito da navegação (marítima), (e) direito romano, (f) direito agrário, (g) direito previdenciário, (h) medicina legal, de elenco compreendendo, ainda, a exigência de "prática forense, sob a forma de estágio supervisionado" e "o estudo de problemas brasileiros e a prática de educação física, com predominância desportiva, de acordo com a legislação específica." etc.

33 Portaria n. 1.886/94/MEC, art. 6": "O conteúdo mínimo do curso jurídico, além do estágio, compreenderá as seguintes matérias, que podem estar contidas em uma ou mais disciplinas do currículo pleno de cada curso. I - fundamentais: introdução ao direito; filosofia (geral e jurídica); ética geral e profissional; sociologia (geral e jurídica); economia e ciência política (com teoria geral do estado); II - profissionalizantes: direito constitucional, direito civil, direito administrativo, direito tributário, direito penal, direito processual civil direito processual penal, direito do trabalho, direito comercial e direito internacional. Parágrafo único: as demais matérias e novos direitos serão incluídos nas disciplinas em que se desdobrar o currículo pleno de cada curso, de acordo com suas peculiaridades e com observância de interdisciplinaridade."

34 RODRIGUES, Horácio Wanderlei. Novo currículo mínimo dos cursos jurídicos. São Paulo: Revista dos Tribunais, 1995, cap. 3, ‘a Portaria n. 1.886/94/MEC e o novo currículo mínimo dos cursos jurídicos', p. 62-93.

35 Geraldo Eulálio do Nascimento e Silva (1917-2003) costumava lembrar, ter sido graças ao empenho de Vicente Marotta Rangel (1924-2017), durante os quase trinta anos em que regeu essa cátedra, de 1966 até 1994, nunca se ter deixado de ensinar direito internacional nas Arcadas! 
O aumento do número e da diversidade dos interlocutores torna ainda mais necessário os mecanismos de composição entre estes. Esse dado é crucial, para a compreensão do direito internacional do tempo presente.

16. Existe relevante produção brasileira de direito internacional a ser resgatada. O que poderia e deveria abranger, desde autores recentes - cujos cursos, ministrados na Academia de direito internacional, da Haia, merecem tradução e publicação no Brasil ${ }^{36}$ - até que se possa voltar aos precursores nacionais do direito das gentes, como a pioneira contribuição de J. M. Avelar Brotero. Outros especialistas cultivaram a matéria, em suas diferentes facetas, ao longo destes quase dois séculos. Muitas das suas obras não se encontram disponíveis. Esse acervo relevante de produção nacional em direito internacional merece ser resgatado.

O mesmo propósito deve nortear o direito internacional em nosso contexto de crise de pós-modernidade. Porquanto as necessidades de ordenação da convivência social, bem como entre sociedades permanecem as mesmas. Mas aumentou a complexidade do mundo, no qual estas normas devem ser aplicadas.

17. Aí se inscreve programa de trabalho e a compreensão do papel da disciplina, cuja regência da cátedra me foi confiada: o direito internacional, no contexto pós-moderno, não pode deixar de ser internacional, no sentido de não se pautar somente pelas prioridades e pelas escolhas nacionais - vimos os maus frutos disso, tanto fora como entre nós, mas, sobretudo, não se pode curvar aos ditames dos poderosos do momento, em detrimento de seu conteúdo humano. E de seu caráter humanista.

O contexto da pós-modernidade mostra a falibilidade dos modelos antes vistos como infalíveis. É a percepção da mortalidade da civilização, da fragilidade das construções do espírito humano, o alerta ao risco de retomada da barbárie, da pretensão do uso da força, como meio de imposição de uma vontade hegemônica, em detrimento da construção do diálogo. Constrói-se como sistema, e aperfeiçoa-se este sistema, como mecanismos normativos e procedimentais.

18. O direito internacional, no presente contexto pós-moderno, deve levar em conta a lição dos mestres do passado, não para retomar o que existia quanto estes escreveram - o que era, de ponto de vista institucional-normativo bastante incipiente mas merece ser preservado ante o perigo de 'nacionalização' do direito internacional, como se tentou fazer, em determinadas épocas e quadrantes, em prejuízo do que seja o direito internacional e do papel que este possa ter na regulação da sociedade humana. Por

36 Tal como foi feito com o curso de SETTE-CÂMARA, José. Poluição de rios internacionais. Tradução e posfácio de Arthur Roberto Capella Giannattasio, Coordenação da edição brasileira e prefácio de Paulo Borba Casella. São Paulo: Quartier Latin, 2011, publicado originalmente: SETTE-CAMARA, José. Pollution of international rivers. Recueil des Cours de l'Académie de Droit International, Leinden/Boston, v. 186 , p. 117-218, 1984. 
isso a necessidade de consciência do papel que tem a desempenhar o direito internacional, em todas as sociedades humanas, sobretudo no tempo presente.

Antes do momento presente existe e cabe recordar o papel desse conjunto de encadeamento e de sucessão do ensino do direito internacional, ao longo destes quase duzentos anos, aqui nas Arcadas. A trajetória da casa ilustrará sobejamente a trajetória nacional.

19. Dentre as primeiras obras de direito internacional, publicadas no país, contam-se as Questões sobre presas maritimas, de José Maria Avelar Brotero, editada em $1836,{ }^{37}$ em São Paulo. Em segunda edição, em 1863. ${ }^{38}$

Avelar Brotero, ao encetar o livro (1836), dirigia-se “aos leitores”, com a assertiva:

eu vou tratar de - direito positivo - e por isso o meu desejo e obrigação é mostrar-vos quais os tratados, manifestos e mais peças diplomáticas, que existem sobre o presente objeto; quais as leis, regulamentos e determinações das Nações sobre o seu direito - marítimo particular: quais as decisões dos tribunais das Nações influentes, e quais seus usos e costumes que formam o Direito das gentes tácito ou voluntário. Eu procuro seguir o método ensinado por Klüber - dogmático-histórico - esclarecendo as matérias com fatos, com acontecimentos reais. Recorro ao Direito das gentes absoluto, quando o caso é duvidoso, ou quando sobre ele não concordam as convenções e os usos. Desprezo as opiniões dos antigos escritores (aqueles que tive ao meu alcance),

37 Questões sobre presas maritimas, "oferecidas ao cidadão Rafael Tobias de Aguiar, pelo autor BROTERO, José Maria de Avelar. Questões sobre presas marítimas. 2. ed augmentada. São Paulo: Typographia imparcial - de J. R. de Azevedo Marques, 1863, declara-se "atento venerador" de Tobias de Aguiar e fazlhe dedicatória: "Com a proteção de V. Exa. me animo a fazer publicar uma pequena obra com o título - Questões sobre presas marítimas - fruto de algum trabalho, e que julgo servirá para dar algumas idéias àqueles que tem de julgar e defender objetos tão interessantes. / A benevolência de V.E. relevará a falta de estilo, e os erros da doutrina; doutrina assaz espinhosa e bem pouco conhecida entre nós. Não tendo eu ao meu alcance senão os meus próprios livros, hei de por força cair em omissões.” (...) Exemplar da Biblioteca da FDUSP.

38 BROTERO, José Maria de Avelar. Questões sobre presas marítimas. 2. ed augmentada. São Paulo: Typographia - imparcial - de J. R. de Azevedo Marques, 1863, registrava no prólogo: “Conheço que este meu trabalho é imperfeito, e muito sinto que nesta segunda edição ficasse com tantos erros, resta-me a esperança que os homens competentes hão de ter indulgência com tais defeitos, e só censurar a doutrina e nesta parte peço-lhes severidade, pois pedir considerações seria ter em pouco a ciência e o meu dever. / Este livro não é uma obra de teorias ou doutrinas especulativas; é um compêndio de fatos e princípios do Direito Marítimo admitido pelas nações civilizadas. / Da primeira edição suprimi tudo quanto me pareceu fora da matéria, aumentei porém muita doutrina que faltava. / Cito os escritores, de que tenho notícia, que publicaram suas obras depois da minha primeira edição - 1836. / Nesta segunda edição procurei ser útil aos meus Escolares, no estudo do Direito das Gentes, e não olhei, nem me lembrei, que o meu trabalho pudesse ser estimado pela elegância e pureza de linguagem". Exemplar da Biblioteca da FDUSP. 
que só se fundam no Direito romano ou seguem opiniões particulares, filhas ou da localidade, ou do partido. ${ }^{39}$

20. Ao considerar "que direito a Nação adquire por meio da guerra" (par. XXIII) ${ }^{40}$ deixava clara a sua lição, o nosso Brotero: "Verdadeiramente a guerra não tem outro fim senão - paralisar as forças do inimigo obrigando-o desta maneira a reconhecer os princípios de eqüidade, e prestar-nos a justa satisfação."

Os limites ao uso da força constituem, ainda, lição crucial para todo o conjunto do direito das gentes. E a determinação de tais limites continua a ser objeto de controvérsias. $^{41}$

21. Caberia referir, ainda, outra obra, Princípios de direito natural "compilados por José Maria Avelar Brotero, lente do primeiro anno do curso jurídico de São Paulo", publicado no Rio de Janeiro, na “Typographia Imperial Nacional”, em 1829. Esta obra, pioneira e curiosa, merece ser resgatada.

Mesmo se os Princípios de direito natural (1829) ${ }^{42}$ somente incidentalmente tratam de questões do que hoje se estuda como direito internacional, a Avelar Brotero teria cabido não somente escrever a primeira obra de direito internacional do Brasil, como esta

39 BROTERO, José Maria de Avelar. Questões sobre presas marítimas: Offerecidas ao cidadão Rafael Tobias de Aguiar. São Paulo: Typ. Costa Silveira, 1836. ("aos leitores", sem número de página): "Muitas vezes, na confusão dos pareceres dos JJ. entre si contraditórios eu me animo a dar a minha opinião. A legislação pátria é citada nos lugares competentes. Muito desejava alegar os julgamentos dos nossos tribunais, mas não estava ao meu alcance poder satisfazer o meu desejo. / Eu conheço que o meu trabalho está bem longe da perfeição e conheço que ele está muito longe de poder conseguir o seu fim: conheço e confesso que não tive à mão nem a legislação das Nações do norte da Europa, nem muitos bons autores que tem tratado desta matéria, e que eu devia consultar; mas minha consciência está convencida de que esta minha pequena obra sempre há de prestar alguma utilidade aos meus escolares, e ao público. Julgo que a matéria é muito interessante, e que por esta razão o governo, e os sábios, não me deixarão continuar a transmitir na aula minhas opiniões à mocidade, uma vez que elas sejam falsas. O governo me advertirá e os sábios me esclarecerão, com suas luzes, por meio da imprensa". Como se vê, adotava redação diversa da que figura na segunda edição (1863).

40 BROTERO, José Maria de Avelar. Questões sobre presas marítimas: Offerecidas ao cidadão Rafael Tobias de Aguiar. São Paulo: Typ. Costa Silveira, 1836. p. 105-110; BROTERO, José Maria de Avelar. Questões sobre presas marítimas. 2. ed augmentada. São Paulo: Typographia - imparcial - de J. R. de Azevedo Marques, 1863. p. 88-90.

41 CASELLA, Paulo Borba. ONU pós-KELSEN. In: MERCADANTE, Araminta de Azevedo; MAGALHÃES, José Carlos de. (Org.). Reflexões sobre os 60 anos da ONU. Ijuí: Editora Unijuí, 2005. p. 13-64.

42 BROTERO, José Maria de Avelar. Princípios de direito natural. Rio de Janeiro: Typografia Imperial e Nacional, 1829. "compilados por José Maria Avelar Brotero, lente do primeiro anno do curso jurídico de São Paulo". Exemplar da Biblioteca da FDUSP. 
precede em três anos a publicação dos Principios de derecho de gentes (1832), de Andrés Bello, ${ }^{43}$ obra marcante na sua produção ${ }^{44}$ e na bibliografia latino-americana. ${ }^{45}$ 22. Nos Princípios de direito natural (1829), adverte Brotero "Aos Leitores": "Se a vossa censura é filha da maledicencia e capricho, sois uns entes nullos no Universo; se ella porém é filha do amor da verdade, então sois homens bem fazejos, e imitaes ao Creador. / São Paulo, 21 de dezembro de 1828 / J. M. A. B."

Avelar Brotero considera o "estado de necessidade" (par. 23, p. 40-42): "A faculdade moral de desprezar a lei mais fraca, para que se obedeça, por causa do conflito, à lei mais forte, se chama direito de necessidade." Detalha três hipóteses deste: " 1 ". Direito de necessidade absoluta e hipotética extrema; $2^{\circ}$. Hipotética não extrema; $3^{\circ}$. Necessidade simples, isto é, sem complicação de perfeições". ${ }^{46}$

23. Expunha Brotero a sua compreensão a respeito do "direito"47 e do "direito natural". 48

43 Originalmente publicada em 1832, conta segunda edição: BELLO, Andrés. Principios de derecho de gentes. Sucre: Imprenta de Beeche y Compañia, 1844. Ver tb. a edição da obra completa de BELLO, Andrés. Derecho internacional. Caracas: Ed. del Ministerio de Educación, 1954. (I. Principios de derecho internacional y escritos complementarios; v. 10); BELLO, Andrés. Derecho internacional. Caracas: Ed. del Ministerio de Educación, 1959. (II. Temas de política internacional; v. 11).

44 BELLO, Andrés. Gramática de la lengua castellana destinada al uso de los americanos. Madri: EDAF, 1984. (11. ed., 2001). Para Bello, o dicionário dá o significado das palavras; a gramática deve tratar as inflexões (morfologia) e as combinações (sintaxe): "En realidad, las varias clases de palabras no difieren unas de otras por su significado, sino por su conexión y dependencia mutua en el lenguaje".

45 Andrés Bello mereceria ser mais e melhor estudado entre nós, por sua preocupação com a identidade e as necessidades latino-americanas. Dentre os formadores de identidade nacional, de vários países do nosso contexto continental. É tanto surpreendente quanto inexplicável que se escreva sobre "Direito internacional na América Latina" sem citar a obra de Andrés Bello!

46 Para dar indício de quanto permanece atual o tema do estado de necessidade em direito internacional foi objeto do inteiro colóquio de Grenoble, da Sociedade francesa para o direito internacional, realizado de 8 a 11 de junho de 2006: Société française pour le droit international, la necessité en droit international (colloque de Grenoble, Paris: Pedone, 2007) onde o eixo das discussões se põe entre «nécessité fait loi» e «nécessité n'a point de loi», ou seja, a necessidade faz a lei, ou a necessidade não tem lei?

47 BROTERO, José Maria de Avelar. Princípios de direito natural. Rio de Janeiro: Typografia Imperial e Nacional, 1829. (seção 4a , p. 12-13) a respeito de "direito" refere: "Direito toma-se em diferentes acepções, $1^{\circ}$. no sentido metafórico significa uma linha reta, uma norma fácil e breve de conseguir qualquer fim; $2^{\circ}$. toma-se por tudo o que é bom e conveniente; toma-se no mesmo sentido da ciência de jurisprudência, isto é a aptidão da razão em conformar as suas ações com a determinação ou proibição da lei. Tem mais duas significações próprias em jurisprudência, e as quais quase sempre são usadas; e vem a ser: $1^{\circ}$. a faculdade moral, que o homem tem de obrar, ou deixar de obrar, qualquer ação, isto é, a faculdade moral cultivada pelo conhecimento da própria razão; $2^{\circ}$. o vocábulo direito se usa tomar pela mesma lei, ou por um complexo de leis, e neste sentido é que nós o devemos agora tomar, por exemplo; direito natural complexo de leis da natureza; direito civil pátrio complexo de leis da nossa nação; direito eclesiástico complexo das leis que regulam a Igreja. Conforme a direito $i d$ est a lei. Direito, obrigação, lei, ofício, são correlativos, isto é não podem existir uns sem que existam os outros."

48 BROTERO, José Maria de Avelar. Princípios de direito natural. Rio de Janeiro: Typografia Imperial e Nacional, 1829: o direito natural será considerado a partir da definição que deste se dá (par. 32, p. 55-59), seguindo-se a demonstração da existência do direito natural (par. 33, p. 59-60), a divisão do direito natural (par. 34, p. 61-68), caracteres e fim do direito natural (par. 35, p. 69-76), derivação do nome direito natural 
Segue-se curioso enunciado da "opinião do compêndio" (par. 44, p. 88-89): "O compêndio está certo da existência do tribunal da consciência, e certo da impossibilidade da sua não existência; mas o mesmo compêndio julga que só deve existir consciência, falando no rigor da definição, quando existir certeza" ${ }^{49}$

24. Brotero, nos Princípios de direito natural (1829, cap. 2, p. 106 e ss.) considera "o homem" e chega à conclusão geral (par. 58, p. 122):

Depois de se fazer análise da variedade dos homens, depois de se ter observado a fisiologia e zoologia, e a história do mesmo homem relativa às artes e ciências, deve-se concluir que o gênero humano é todo de uma espécie, e que existe no homem unidade, e que a lei da natureza ou a jurisprudência natural, é comum a todas as variedades ou famílias, tendo todas elas iguais direitos, iguais obrigações e iguais ofícios.

Seguiam-se considerações de Brotero a respeito da "alma", ${ }^{50} \mathrm{da}$ "liberdade", ${ }^{51}$ bem como: definição de pensar (par. 66, p. 148-151), dom da palavra (par. 67, p. 152-154), origem do dom da palavra e razão dos diferentes idiomas (par. 68, p. 154-156). ${ }^{52}$

(par. 36, p. 77), utilidade do direito natural (par. 37, p. 78), justiça (par. 38, p. 78-79), consciência e suas divisões (par. 39, p. 79-80), consciência nada mais é do que a razão (par. 40, p. 80-82), como devemos usar da nossa consciência (par. 41, p. 82-85), evidência e sua divisão (par. 42, p. 85-86), principais regras que devemos seguir a respeito da nossa consciência (par. 43, p. 86-88).

49 BROTERO, José Maria de Avelar. Princípios de direito natural. Rio de Janeiro: Typografia Imperial e Nacional, 1829: virão a seguir: regras que devemos seguir (par. 45, p. 89), sanção da consciência ou efeitos da consciência moral (par. 46, p. 89-94), consciência e imputação em geral são correlativos (par. 47, p. 94-96), explicação destas divisões (par. 48, p. 96-99), continuação do par. 47 (par. 49, p. 99-101). A “regra geral" (par. 50, p. 102): "Temos até agora mostrado que consciência e imputação são correlativos; temos visto que todas as ações que não tem moralidade nem imputação, não tem ou não podem ter sentença da nossa consciência, e por isso o compêndio vai estabelecer a seguinte regra geral. - Toda a ação humana, seja ela qual for, que depois de analisada se vê ter sido praticada sem conhecimento, vontade e liberdade, não pode sofrer o julgamento da nossa consciência; e esta mesma regra se deve seguir quando a ação pecar, ou por falta só de conhecimento, ou de vontade, ou de liberdade".

50 BROTERO, José Maria de Avelar. Princípios de direito natural. Rio de Janeiro: Typografia Imperial e Nacional, 1829. ("Da alma”, par. 59, p. 123-130) é seguido: da união da alma e do corpo (par. 60, p. 130), da imortalidade da alma (par. 61, p. 131-135), faculdades (par. 62, p. 135-139), entendimento (par. 63, p. 140-145), vontade (par. 64, p. 146): "Vontade é a modificação de nossa alma, pela qual ela dispõe a ação. Esta disposição da ação provém sempre das sensações já representadas na nossa alma, cujas representações chamamos motivos, que devem ser filhos da razão [,] fazem nascer as ações voluntárias, nas quais o homem tem uma perfeita moralidade, e nos quais se executa necessariamente a sanção da lei natural".

51 BROTERO, José Maria de Avelar. Princípios de direito natural. Rio de Janeiro: Typografia Imperial e Nacional, 1829. ("Liberdade", par. 65, p. 146-148): "Liberdade é a faculdade com que a nossa alma, depois de determinar-se a praticar a ação, põe em execução esta mesma determinação". Desse modo, “o homem sendo dotado de liberdade pode pôr ou deixar de pôr em execução todos os atos de sua vontade, até mesmo aqueles que são contraditórios e repugnantes com as leis da natureza; e à primeira vista parece que a jurisprudência natural é injusta, visto que não atalha, não providencia o abuso da mesma liberdade, deixando-a ao homem em pleno exercício, e com uma extensão sem limites".

52 BROTERO, José Maria de Avelar. Princípios de direito natural. Rio de Janeiro: Typografia Imperial e Nacional, 1829. (continuação do par. 68 (par. 69, p. 156-160) onde se consigna (p. 158): “O compêndio 
25. No capítulo terceiro dos Princípios de direito natural (1829), Brotero passa ao exame da "sociedade natural": os homens no estado primeiro viviam bem como as feras (par. 70, p. 161-162), opinião daqueles que querem que o gênero humano no seu estado primevo estivesse em sociedade, tomada esta no rigor da palavra (par. 71, p. 162-164), “opinião do compêndio (traduzido de Filungieri)” (par. 72, p. 164-170), estado conjugal (par. 73, p. 170-181), poligamia (par. 74, p. 181-183), deveres do esposo, e da esposa (par. 75, p. 183-185), do divórcio (par. 76, p. 186-188), deveres dos pais para com os filhos (par. 77, p. 188-190), continuação do par. antecedente (par. 78, p. 191-193), a que pontos se pode reduzir a educação da prole (par. 79, p. 193-196), obrigação dos filhos para com os pais (par. 80, p. 196-198), deveres perfeitos e imperfeitos (par. 81, p. 198199), ofícios menos perfeitos do estado social natural - respeito para com os velhos (par. 82, p. 199-200), deveres menos perfeitos, ou respeito para com as mulheres, em relação ao estado conjugal (par. 83, p. 200-202), respeito que se deve à mocidade (par. 84, p. 202209).

26. No capítulo quarto dos Princípios de direito natural, Brotero passa ao exame dos "direitos do homem". Dentre os quais, a liberdade (par. 85, p. 210-213, e par. 86, continuação da matéria, p. 213-214), “a escravidão é o maior de todos os males" (par. 87, p. 215-216), a liberdade ilimitada é contrária às leis da natureza (par. 88, p. 216-220), liberdade de pensar (par. 89, p. 220-221), liberdade de consciência (par. 90, p. 221-223, e par. 91, continuação da mesma matéria, p. 223-224), a religião revelada deve ser observada pelo gênero humano por determinação da lei natural (par. 92, p. 224226), perigos do fanatismo e da intolerância (par. 93, p. 226-230), igualdade (par. 94, p. 230-233), diferenças das faculdades morais (par. 95, p. 234-235), a diversidade de faculdade faz a diversidade de condições (par. 96, p. 236), de singela conclusão: "Fica acima demonstrado que o desenvolvimento das faculdades intelectuais é diferente nos diferentes homens, e que na razão humana não existe igualdade. Esta variedade da razão produz a desigualdade de condição."

27. Indagava Brotero: "Em que consiste a verdadeira igualdade natural" (par. 97, p. 237):

Igualdade natural dos homens não quer dizer nivelidade natural dos mesmos homens, como já se disse, mas sim significa a dependência mútua, e a reciprocidade de obrigações em que existem eles, uns para com os outros,

bem sabe, que o leitor há de criticar muito e muito por ele ter dado ao corpo organizado sensação; porém paciência: o compêndio só pede, que a crítica seja feita depois de algum estudo, e reflexão; e para melhor se fazer este estudo, e o leitor bem entender este capítulo, ele oferece as duas seguintes tábuas" (com duas litografias do Arquivo Militar): Tábua primeira "diferença entre as sensações" e Tábua segunda "formação das idéias". 
sejam quais forem as suas diferentes condições. Os homens não são iguais no esclarecimento da sua razão, porém são iguais para procurar todos os meios para conseguir este esclarecimento, eles não são iguais nas faculdades físicas, porém tem todos igual direito para procurar todos os meios de melhorar, e aperfeiçoar estas mesmas faculdades.

Os capítulos seguintes tratavam do "direito de propriedade",53 das "convenções", ${ }^{54}$ do que chamava "direito de segurança", ${ }^{55}$ onde Brotero sustentava dividir-se o direito de segurança em direito de defesa e direito de reivindicação, ou jus cogendi. Brotero prosseguia com o exame dos "ofícios". ${ }^{56}$

28. Além dos Princípios de direito natural (1829) e das Questões sobre presas marítimas (1836 e 1863), ainda Brotero publicou Princípios de direito público

53 BROTERO, José Maria de Avelar. Princípios de direito natural. Rio de Janeiro: Typografia Imperial e Nacional, 1829, vinham a seguir: direito de propriedade (par. 98, p. 238-244), o que seja apreensão, posse e ocupação (par. 99, p. 244-245), a quem pertence o animal ferido (par. 100, p. 246), ocupação das cousas imóveis (par. 101, p. 246-247), diferentes modos de adquirir propriedade (par. 102, p. 247-249), se o direito de propriedade secundária é natural, ou adventício (par. 103, p. 249-252), acessão (par. 104, p. 252-255), direitos, que nascem da propriedade (par. 105, p. 255-256), se o estabelecimento da propriedade secundária é útil, ou nocivo ao gênero humano (par. 106, p. 256-259), doação real (par. 107, p. 259-264), doação causa mortis (par. 108, p. 264-265), do mútuo (par. 109, p. 265-267), do comodato (par. 110, p. 267-269), direitos provenientes das doações gratuitas (par. 111, p. 269-271), tradição (par. 112, p. 272-275), permutação (par. 113, p. 276-278, e par. 114, continuação da matéria, p. 278-281).

54 BROTERO, José Maria de Avelar. Princípios de direito natural. Rio de Janeiro: Typografia Imperial e Nacional, 1829. (O capítulo quinto, "das convenções", é precedido de "introdução" (p. 282-284) e "advertência - mais vale tarde que nunca" (p. 284-285), e trata, a seguir: definição e requisitos necessários na convenção (par. 115, p. 286-288), explicação dos requisitos da convenção (par. 116, p. 288-294), condição (par. 117, p. 294-296), da convenção nasce obrigação perfeita (par. 118, p. 297), quando se cumpre a convenção (par. 119, p. 297), do precário (par. 120, p. 297-298), do depósito (par. 121, p. 298-299), do mandato (par. 122, p. 299-306), da agência dos negócios (par. 123, p. 306-309), locação e condução (par. 124, p. 310-321), sociedade de obras (par. 125, p. 321-322), usuras (par. 126, p. 322-325), da sociedade em geral (par. 127, p. 325-329).

55 BROTERO, José Maria de Avelar. Princípios de direito natural. Rio de Janeiro: Typografia Imperial e Nacional, 1829: "este direito, que é universalmente reconhecido como necessário, nos provém diretamente e imediatamente da obrigação da nossa própria conservação, e não da injustiça ou do crime do agressor, tanto assim que nós podemos usar dele contra um inocente; exemplo: contra o homem, que nos ataca obrigado; contra aquele que nos ataca por defeito de razão \& c. Grotius Le droit de la guerre, et de la paix Liv. 2, cap. 1 par. 3, n. 3". Grócio nesta passagem discorre a respeito do direito de se defender e parte da argumentação de Bartolo.

56 BROTERO, José Maria de Avelar. Princípios de direito natural. Rio de Janeiro: Typografia Imperial e Nacional, 1829. (capítulo sétimo trata dos ofícios): ofícios erga Deum (par. 129, p. 336-355), ofícios erga se (par. 130, p. 356-372), paixões (par. 131, p. 372-389), o pudor é uma doação da natureza naturante (par. 132, p. 389-400), o homem nasceu para o trabalho (par. 133, p. 400-402), atividade (par. 134, p. 402-406), interesse, ou amor de nós mesmos (par. 135, p. 407-414), respeito para com a verdade, ou uso que devemos fazer da nossa palavra (par. 136, p. 414-420), suicídio (par. 137, p. 421-427), ofícios erga alios (par. 138, p. 427-435), deveres dos membros de uma mesma família (par. 139, p. 436-437), amizade (par. 140, p. 438-442) e conclusão (par. 141, p. 442-447). Encerra o volume: "Desculpai, meus leitores, meus erros, ficai certos no meu bom desejo, e eu vos serei eternamente grato". 
universal: analyse de alguns paragraphos de Wattel (São Paulo, 1837, 80 p.) $)^{57}$ e Philosophia do direito constitucional (São Paulo, 1868, 166 p.). ${ }^{58}$

José Maria Avelar Brotero (1798-1878) lecionou na Faculdade durante quarenta e quatro anos, observava Waldemar Ferreira (1928), ${ }^{59}$ "pois que se jubilou em 22 de novembro de 1871, de modo que quase durante meio século, a sua vida se entremeou com a da Faculdade de Direito, à qual prestou serviços assinalados, que não podem ser deslembrados, sem embargo de ter o seu compêndio, elaborado para os estudantes, Princípios de direito natural, provocado a crítica mais acerba, a ponto da Comissão de Instrução Pública da Câmara dos Deputados, em 1830, ter apresentado parecer, que foi aprovado, concluindo que não fosse este admitido no curso jurídico, 'devendo-se ensinar o direito natural por outro compêndio, que melhor desempenhe a matéria' ${ }^{60}$

Miguel Reale (1955, 1956, 1962 e 1976) ${ }^{61}$ reporta a respeito: "primeiro lente da Faculdade de Direito de São Paulo, acumulando as funções de secretário com

57 Miguel Reale (1955, editado 1956, 1962 e 1976, cit., nota 17): “Cs. Avelar Brotero - Questões sobre presas marítimas, da qual se tiraram duas edições, uma em 1836 e a outra em 1863, esta com acréscimos. Além deste livro e dos Princípios de direito natural, mais dois foram, com segurança, por ele publicados: Princípios de direito universal, folheto de 80 páginas, aparecido anônimo em 1837, conforme declaração do autor em seu "livro-mestre" (Cs. Traços Biográficos, cit., p. 75) e mais um drama político intitulado Tumulto do povo em Évora, de 102 páginas, publicado também em São Paulo. Por outro lado, Brotero não chegou a publicar os anunciados Princípios históricos compilados para servir de preliminares ao Compendio de direito natural e direito público. É possível que só haja existido apostilas. Sacramento Blake em seu Dicionário Bibliográfico Brasileiro, alude a mais dois trabalhos: Filosofia do direito constitucional (São Paulo, 1868, 166 p.) e Os três primeiros parágrafos de Vattel-Direito das gentes, liv. I, cap. 1. Princípios de direito público universal ou filosofia do direito constitucional, dividido em 20 lições. Creio que esta obra não seja senão o folheto de 80 páginas, acima referido, que também é anônimo, abrangendo número idêntico de páginas e de lições. Há na Biblioteca da Faculdade um exemplar com a dedicatória de Avelar Brotero de próprio punho, com estes dizeres: 'Oferecido à Biblioteca pelo A.' O título dessa edição de 1842 já é diverso, Filosofia do direito constitucional, embora no subtítulo se encontrem as referências a Vattel. Terá havido nova edição dessa obra, ampliada para 116 páginas, em 1868, como afirma Sacramento Blake? É o que não pude averiguar."

58 (Conselheiro) José Maria de Avelar Brotero, A filosofia do direito constitucional. Introdução de José Afonso da Silva. São Paulo: Malheiros, 2007. p. 18-19: "Merece especial destaque este volume, que temos em mãos, A filosofia do direito constitucional (São Paulo, 1842). Miguel Reale acredita que seja este a reprodução daquele folheto de 80 páginas, publicado em 1837. Pode ser, mas talvez reformulado e ampliado. Vale a pena ler e examinar este texto sobre a filosofia do direito constitucional, que apresenta surpresa agradável para o constitucionalismo brasileiro, ainda que ele não seja sobre direito constitucional positivo, pois não se refere à Constituição do Império."

59 FERREIRA, Waldemar. A Congregação da Faculdade de Direito de São Paulo na centuria de 1827 a 1927. Revista da Faculdade de Direito de São Paulo, São Paulo, v. 24, 1928.

60 FERREIRA, Waldemar. A Congregação da Faculdade de Direito de São Paulo na centuria de 1827 a 1927. Revista da Faculdade de Direito de São Paulo, São Paulo, v. 24, 1928. p. 33-34.

${ }_{61}$ REALE, Miguel. Avellar Brotero, ou a ideologia sob as Arcadas. In: REALE, Miguel. Filosofia em São Paulo, 1 ed. São Paulo: Grijalbo, 1962, (publicado originalmente no volume Horizontes do direito e da história: estudos de filosofia do direito e da cultura. São Paulo: Saraiva, 1956. p. 195-224, depois publicado em Filosofia em São Paulo, 1 ed. São Paulo: Grijalbo, 1962 e em Filosofia em São Paulo, 2 ed. rev. e reestruturada. São Paulo: EDUSP/Grijalbo, 1976. p. 63-91. 
proverbial exação, durante quarenta e três anos" (...) "timbrou em ser o mais rigoroso cumpridor dos deveres do magistério, até jubilar-se aos 22 de novembro de 1871, tendo adquirido a cidadania brasileira um lustro após a sua fixação em São Paulo, em junho de 1833". ${ }^{62}$ Relata Reale extensamente a controvérsia em torno do compêndio, Princípios de direito natural (1829). ${ }^{63}$

29. Cabe construir a sucessão dos docentes (ordinários, catedráticos e titulares da cadeira de direito internacional), a partir deste seu primeiro ilustre regente. Conforme registra a Memória histórica acadêmica de 1877, da Faculdade de Direito de São Paulo, "a Faculdade tem tido, desde o dia de sua inauguração os quarenta lentes seguintes, dos quais 12 jubilaram-se, 6 faleceram no exercício do cargo, e 6 demitiram-se deste". ${ }^{64}$ Jubilaram-se:

"1'. Dr. J. M. de Avelar Brotero, que foi nomeado por Decreto de 12 de outubro de 1827 , e jubilou-se em 1871 ” (...)

" 6 ". Conselheiro Dr. Manuel Joaquim do Amaral Gurgel, que, nomeado a 20 de fevereiro de 1834, jubilou-se em 1859”. Amaral Gurgel foi também diretor da Faculdade, nomeado por Decreto de $1^{\circ}$. de dezembro de 1837, tomou posse a 23 de fevereiro de 1838 ".

Avelar Brotero $^{65}$ e Amaral Gurgel teriam, assim, regido, alternadamente a cadeira de direito das gentes. De 1827 a 1871, no caso do primeiro, e de 1834 até 1859 , no caso do segundo.

30. Manoel Joaquim do Amaral Gurgel nasceu em São Paulo, a 8 de setembro de 1797, onde faleceu a 15 de dezembro de $1864 .{ }^{66}$ Participou do movimento da

62 REALE, Miguel. Avellar Brotero, ou a ideologia sob as Arcadas. In: REALE, Miguel. Filosofia em São Paulo, 2 ed. rev. e reestruturada. São Paulo: EDUSP/Grijalbo, 1976. p. 63-91, (p. 64, nota 1, cita): "Notas" autobiográficas, coligidas em BROTERO, Frederico de Barros. Traços biográficos do Conselheiro José Maria Avelar Brotero, por seu neto. São Paulo: [s.n.], 1933. p. 71 e ss.

63 REALE, Miguel. Avellar Brotero, ou a ideologia sob as Arcadas. In: REALE, Miguel. Filosofia em São Paulo, 2 ed. rev. e reestruturada. São Paulo: EDUSP/Grijalbo, 1976. p. 74: "O que nos atrai, todavia, na personalidade de Brotero, não são as atitudes do ranzinza impenitente ou do orador que baralhava sílabas e frases, mas sim a significação histórica, mais do que o valor intrínseco de sua obra filosófica-jurídica, inclusive para compreender-se melhor a sua presença na cátedra de direito natural durante quase meio século".

${ }^{64}$ FACULDADE DE DIREITO DE S. PAULO. Memória histórica acadêmica de 1877. São Paulo: [s.n.], 1878. p. 2, (catálogo da Biblioteca central da Faculdade de Direito da U.S.P. 378.4: 34(816.1) (091) RC F378.4 F128m e.7 S.E. tombo 09/87, cit. p. 2) com as observações já referidas do "lente substituto", Dr. Joaquim Augusto de Camargo.

65 CENTRO DE DOCUMENTAÇÃO DO PENSAMENTO BRASILEIRO. Dicionário biobibliográfico de autores brasileiros. Salvador: CDPB; Brasília: Senado Federal, 1999. p. 119-120: "Coube-lhe a missão de implantar o curso jurídico em São Paulo, sendo o seu primeiro lente e acumulando as funções de secretário (cargo que exerceu por mais de quarenta anos)".

66 MELO, Luís Correia de. Dicionário de autores paulistas. São Paulo: Comissão do IV Centenário da Cidade de São Paulo, 1954, p. 273: “Aprendeu as primeiras letras com a sua madrinha e parenta, Maria Policena do Amaral Gurgel, que se encarregou dos cuidados de criá-lo e educá-lo. Depois do estudo do latim com o 
independência, tendo sido, por isso, deportado. Formou-se, em 1832, pela Faculdade de Direito de São Paulo, onde se doutorou, em 1834. Ocupou a cátedra de filosofia no curso anexo (1829), lente substituto da Faculdade de Direito (1833), deputado provincial (1834, 1842, 1847, 1848), diretor interino (1837) e diretor efetivo da Faculdade de Direito, vicepresidente da província (1859-1864).

Amaral Gurgel foi poeta, tradutor do Catecismo de Bossuet, também historiador e biógrafo: a ele devemos a Notícia biográfica do general José Arouche de Toledo Rendon (São Paulo, 1843) - o primeiro diretor da Faculdade; bem como, no mesmo ano, a Oração fúnebre por ocasião das exéquias feitas ao revdmo. sr. padre Diogo Antonio Feijó, na igreja do convento do Carmo de São Paulo, em 1843 (São Paulo, 1843, 12 p., in $8^{\circ}$.).

31. Ainda caberá suprir a lacuna que nos resta, quanto às datas exatas do exercício da titularidade da cadeira de direito das gentes na Faculdade de Direito de São Paulo, ${ }^{67}$ nos vinte anos, entre a jubilação de seu primeiro regente, J. M. de Avelar Brotero, em 1871, até que se aponte o programa de ensino, apresentado em 1891, pelo catedrático Jesuíno Ubaldo Cardoso de Mello. Alguns nomes apontam, mas o exato encadeamento de tal sucessão faz falta.

Da pesquisa nos anuários da Faculdade de Direito, de 1891 até 1969, extraise a seguinte evolução do ensinamento do direito internacional na nossa casa: ${ }^{68}$ Jesuíno Ubaldo Cardoso de Mello, em 1891 e 1892, rege a primeira cadeira da segunda série do curso de ciências sociais, "Direito das gentes, diplomacia e história dos tratados". Não há registro para 1893.

32. Em 1894 o programa de ensino de "Direito das gentes, diplomacia e história dos tratados" foi apresentado pelo "lente cathedratico", Dr. Américo Brasiliense de Almeida Mello. Mais um lente catedrático de direito das gentes da casa que se tornará nome de rua desta cidade: Américo Brasiliense!

professor André da Silva Gomes, matriculou-se no curso de teologia, que acabava de instalar-se no convento do Carmo, sob a direção de Frei Antonio do Bom Sucesso Mamede. Mais tarde, inaugurada no convento de São Francisco, a aula de filosofia de Mont'Alverne, inscreveu-se entre os seus discípulos. Pouco depois (1820), tendo-se instruído em outras disciplinas, foi nomeado pelo bispo D. Mateus, para reger a cadeira de história eclesiástica, recém-criada no seminário de São Paulo, substituindo ao mesmo tempo, o professor de exegética. Em 1816 recebeu ordem de presbítero, com dispensa da autoridade eclesiástica, por não ter idade legal. Foi, em 1821, nomeado examinador sinodal do bispado."

67 SOARES, Guido Fernando Silva. Curso de direito internacional público. São Paulo: Atlas, 2002. v. 1. p. 15-16, aponta, após o seu primeiro catedrático, o Conselheiro Avelar Brotero, ao qual (sic) "se seguiram os mestres Amaral Gurgel" (porquanto este a regeu alternadamente com o primeiro, de 1834 até 1859). A seguir menciona Ferreira França, sem dar deste as datas, seguido de Oliveira Coutinho, João (sic, José) Mendes, Brás Arruda e Vicente Marotta Rangel.

68 Proficiente e cuidadoso levantamento Pesquisa nos Anuários da Faculdade de Direito (1891 a 1969), desenvolvido pela equipe da Biblioteca da Faculdade de Direito da Universidade de São Paulo, sob a direção da Dra. Maria Lúcia Beffa. A toda a equipe, mais uma vez, meus efusivos agradecimentos. 
Em 1895, 1896 e 1898, o programa de ensino de "Direito internacional público e diplomacia" foi apresentado pelo "lente cathedratico", Dr. Alfredo Lima. Não há registro para o ano de 1897.

33. Nos anos de 1899 e 1900, o programa de "Direito internacional público e diplomacia" foi apresentado pelo "lente substituto", Dr. José Mariano Corrêa de Camargo Aranha. Este docente, em 1901, passa a ser "lente cathedratico" e o programa, por vez primeira, menciona "Direito internacional público e privado e diplomacia".

De 1902 até 1911, o programa, com a mesma denominação "Direito internacional público e privado e diplomacia", é apresentado pelo "lente substituto", Dr. José Bonifácio de Oliveira Coutinho.

34. Outro professor de direito internacional da nossa casa foi José Mendes (1861-1918). ${ }^{69}$ Por decreto de 3 de novembro de 1911 foi nomeado professor ordinário da cadeira de direito internacional público e privado, da qual tomou posse em 11 do mesmo mês. $^{70}$

De José Mendes foram publicadas as obras: Ensaios de philosophia do direito. Edição do autor. São Paulo: Duprat \& Cia., 1905. 2 v, Das servidões de caminho: direito romano e pátrio. São Paulo: Duprat \& Cia., 1906, Direito internacional publico: prelecções. São Paulo: Duprat \& Comp., 1913. ${ }^{71}$

Para compreender o contemporâneo é preciso entender o que veio antes e poder conferir coerência ao conjunto, mediante a compreensão do que precede, para se chegar ao ora existente e daí para o que poderá vir a seguir. Destacar um momento fará perder a compreensão do todo.

Dediquei à obra de José Mendes estudo, por ocasião do centenário da publicação da sua principal obra. ${ }^{72}$

35. "O direito está para o organismo social”, dizia José Mendes (1913), ${ }^{73}$ "como a veste para o organismo individual: um e outro acompanham o desenvolvimento

69 CENTRO DE DOCUMENTAÇÃO DO PENSAMENTO BRASILEIRO. Dicionário biobibliográfico de autores brasileiros. Salvador: CDPB; Brasília: Senado Federal, 1999. p. 317-318.

70 FERREIRA, Waldemar. A Congregação da Faculdade de Direito de São Paulo na centuria de 1827 a 1927. Revista da Faculdade de Direito de São Paulo, São Paulo, v. 24, 1928. p. 109-110.

71 FERREIRA, Waldemar. A Congregação da Faculdade de Direito de São Paulo na centuria de 1827 a 1927. Revista da Faculdade de Direito de São Paulo, São Paulo, v. 24, 1928. p. 109-110, menciona, inadvertidamente, 1915 como data da publicação do Direito internacional público: prelecções do Dr. José Mendes "Professor ordinário da Faculdade de Direito de São Paulo". Essa obra de José Mendes foi publicada em 1913.

72 CASELLA, Paulo Borba. Cem anos do Direito Internacional Público (1913) de José Mendes (1861-1918): olhar reflexivo sobre o Direito Internacional nas Arcadas (1911-1918). Revista da Faculdade de Direito da Universidade de São Paulo, São Paulo, v. 108, p. 27-44, jan./dez. 2013.

73 MENDES, José. Direito internacional publico: prelecções. São Paulo: Duprat \& Comp., 1913, ('prefácio', datado de 15 de novembro de 1913): "Este livro reflecte em synthese as minhas prelecções de direito internacional público, na Faculdade de direito de São Paulo. / Transumpto da explicação de todas as theses 
do respectivo corpo. Cada fase da evolução social contém a fase anterior, com alguma coisa a mais. Cada fase é o resumo das fases anteriores, numa e noutra evolução", retomaria J. Mendes (1918). ${ }^{74}$

José Mendes apontava com discernimento o papel a ser desempenhado pelo direito internacional: "este ramo da árvore jurídica em formação, adaptado à sociedade internacional, civitas maxima, societas societatum, ora também em formação e cujas condições de vida e desenvolvimento exigem, como as da sociedade nacional, reconhecimento e garantias tendentes à manutenção do equilíbrio das esferas de atividade dos estados, unidades do organismo social mundial". ${ }^{75}$

36. Theophilo Benedicto de Souza Carvalho (nascido em 1869-? - ainda vivia em 1927), "exerce a advocacia em São Paulo" relata W. Ferreira (1928) ${ }^{76}$ foi nomeado professor catedrático de direito internacional público e privado, por decreto de 29 de maio de 1918, da qual tomou posse em 10 de junho seguinte. Sucede, assim, a José Mendes (1861-1918). ${ }^{77}$

de meu programma, traz a nomenclatura de todas as questões de mais destaque no assumpto, discutidas e resolvidas durante o curso. / Contém as linhas essenciaes dos institutos jurídico-mundiaes, sem descer a detalhes, consoante já aconselhavam os Estatutos da Universidade de Coimbra de 1772. / A linguagem é simples, conforme o salutar exemplo dos modernos expositores da matéria scientífica. Sciencia e rhetorica são coisas que se não attraem. ORNARI RES IPSA VETAT, CONTENTA DOCERI."

74 MENDES, José. Relação entre o direito internacional publico e o direito nacional nos paizes americanos. Revista dos Tribunaes, São Paulo, v. 24, p. 81, 1917.

75 MENDES, José. Direito internacional publico: prelecções. São Paulo: Duprat \& Comp., 1913 ('prefácio') encerrava-o: "É, pois, um manual de estudantes. Escrevel-o custou-me grande somma de exforços, a que me não poupei, cônscio do intento de satisfazer a uma necessidade vivamente sentida e repetidamente manifestada por meus discípulos, a cujas mãos o entrego, certo de que farão delle um dos factores do progresso de nossa cultura jurídico-internacional."

76 FERREIRA, Waldemar. A Congregação da Faculdade de Direito de São Paulo na centuria de 1827 a 1927. Revista da Faculdade de Direito de São Paulo, São Paulo, v. 24, 1928. p. 116: "Inscreveu-se em vários concursos abertos na Faculdade de Direito de São Paulo, em 1897, em 1902, em 1909, em 1910 e 1911. Disputou a livre-docência em 1911 e a obteve em 28 de outubro de 1914 com o Dr. Manoel Aureliano de Gusmão. Neste mesmo ano, por decreto de 20 de outubro, foi nomeado professor extraordinário efetivo da primeira seção. Tomou posse em 28 do mesmo mês, recebendo o grau de doutor."

77 Sobre o autor veja-se: COSTA, José da Silva. Carta do eminente jurisconsulto: In: MENDES, José. Ensaios de filosofia do direito. São Paulo: Duprat, 1905; VAMPRÉ, Spencer. Memórias para a história da Academia de São Paulo. 2. ed. Brasília: INL; Conselho Federal de Cultura, 1977. p. 427-429; CENTRO DE DOCUMENTAÇÃO DO PENSAMENTO BRASILEIRO. Dicionário biobibliográfico de autores brasileiros. Salvador: CDPB; Brasília: Senado Federal, 1999. p. 317-318, registra a respeito de José Mendes: "Nasceu no interior de Minas Gerais, a 27 de março de 1861. Diplomou-se pela Escola Normal de Campanha, dedicando-se ao magistério secundário. Mais tarde transferiu-se para São Paulo, matriculando-se na Faculdade de Direito, bacharelando-se em 1891. Passou, então, a advogar no interior paulista (Mococa). Em 1911 ingressou no corpo docente da Faculdade, onde chegou a catedrático e teria a oportunidade de reger a cadeira de filosofia do direito (?). Foi membro fundador do Instituto dos Advogados de São Paulo. Morreu assassinado em Mococa, a 28 de março de 1918, aos 57 anos." A bibliografia de José Mendes inclui, ainda, Das servidões de caminho: direito romano e pátrio. São Paulo: Duprat \& Cia., 1906 e Ensaios de philosophia do direito. Edição do autor. São Paulo: Duprat \& Cia., 1905. 2 v., além de seu já referido Direito internacional publico: prelecções. São Paulo: Duprat \& Comp., 1913. 
Em 1918, pela primeira vez, o ensinamento de direito internacional, na Faculdade de Direito de São Paulo cinde-se em: direito internacional público, $1^{\mathrm{a}}$. cadeira do $2^{\circ}$ ano, "apresentado pelo professor catedrático Dr. José Mendes e adotado para o ano de 1918, pelo professor doutor Theophilo B. de Souza Carvalho", enquanto o "programa de ensino de direito internacional privado, $5^{\text {a }}$. cadeira do $5^{\circ}$. ano", foi igualmente apresentado pelo mesmo catedrático, Dr. José Mendes.

37. Souza Carvalho prosseguirá com o ensino do direito internacional privado até 1938. Nesse mesmo ano, consta menção ao "programa do Prof. Dr. Theophilo B. de Souza Carvalho, adotado pelo Prof. Dr. Antonio de Sampaio Dória”.

Concomitantemente a Souza Carvalho, desenvolver-se-á o trabalho de Braz de Souza Arruda, como regente de "direito público internacional", este a partir de $1921 .{ }^{78}$ 38. Antonio de Sampaio Dória (1883-1964), cursou a Faculdade (19041908) lecionou também direito internacional, em nossa escola. ${ }^{79}$ Aprovado em concurso para substituto da segunda seção da Faculdade de Direito de São Paulo, em 1919, foi nomeado livre-docente de direito público e constitucional e de direito internacional público e privado. Foi também ministro da Justiça (1945-46).

Aberta a vaga de professor catedrático de direito público e constitucional, "pelo ter sido posto em disponibilidade o Dr. Herculano de Freitas", inscreveu-se o obteve o primeiro lugar.

39. Os nomes de Sampaio Dória e de Braz de Souza Arruda permanecem, lado a lado, até 1945.

Braz de Souza Arruda (1895-1963), ${ }^{80}$ foi nomeado professor catedrático de direito público internacional por decreto de 6 de maio de 1925, tomando posse da cadeira em 14 do mesmo mês. ${ }^{81}$ Foi também diretor da Faculdade (1949-1955). Vangloriava-se

78 ARRUDA, Braz de Souza. Curso de direito internacional na era atômica. Curitiba - São Paulo - Rio: Guaíra, [19??], mencionava no 'Cavaco', p. 5-11: “O calourinho de 1912 completou 25 anos de cátedra em 1945! / Que foi minha vida de professor? Fazendo um exame de consciência posso afirmar que, como mestre de Direito, não envergonhei a rota seguida na minha vida acadêmica."

79 A respeito deste, refere FERREIRA, Waldemar. A Congregação da Faculdade de Direito de São Paulo na centuria de 1827 a 1927. Revista da Faculdade de Direito de São Paulo, São Paulo, v. 24, 1928. p. 130-131: matriculou-se em 1904, bacharelou-se em 1908 na Faculdade de Direito de São Paulo.

80 FERREIRA, Waldemar. A Congregação da Faculdade de Direito de São Paulo na centuria de 1827 a 1927. Revista da Faculdade de Direito de São Paulo, São Paulo, v. 24, 1928. p. 124) a respeito de Braz de Souza Arruda: matriculou-se em 1912, bacharelou-se em 1916. Em 1917, prestou concurso e foi aprovado, por unanimidade de votos. Foi nomeado livre-docente, por portaria de 2 de maio de 1919, tomando posse na mesma data. Por decreto de 23 de junho de 1920, aprovado em novo concurso, foi nomeado professor substituto da segunda seção, tomando posse em 5 de julho, quando recebeu o grau de doutor.

81 FERREIRA, Waldemar. A Congregação da Faculdade de Direito de São Paulo na centuria de 1827 a 1927. Revista da Faculdade de Direito de São Paulo, São Paulo, v. 24, 1928. p. 124: "É o mais jovem dos professores da Faculdade de Direito de São Paulo. / Operoso, tem publicado vários trabalhos jurídicos na Revista da Faculdade de Direito de São Paulo, vols. 21 e 22, e, em volume, editou as suas dissertações de concurso, em 1919." 
Braz de Souza Arruda $(\mathrm{s} / \mathrm{d})^{82}$ ter sido o primeiro a tratar do direito aeronáutico e dos efeitos jurídicos da radiofonia no Brasil.

40. Em 1939 e 1940, ao lado da regência da cadeira de "direito público internacional", por Brás de Souza Arruda, apresenta-se o "programa de direito internacional privado" do livre-docente prof. Manuel Francisco Pinto Pereira.

Para M. F. Pinto Pereira (1920), ${ }^{83}$ “o nosso século, que ao ius inter gentes há de traçar liames mais estreitos, muito terá caminhado si conseguir uma obediencia mais efficaz àquele velho princípio fundamental do direito, que é a base universa de quaisquer normas jurídicas. O ideal dos indivíduos, para o qual convergem todas as forças, é a realisação do direito; como também essa realisação é o ideal mais alto, à volta do qual, nas relações internacionaes, os esforços das gentes se intensam.

\section{Prosseguia:}

Quando a justiça prescreve direitos eguaes às nações, não quer que ellas se façam eguaes de facto, senão que se respeitem umas às outras, conforme são, no que são, pelo que são. Em tudo, como em toda parte, onde se praticar o direito, os mais intrincados problemas se reduzem à expressão mais simples pelo suum cuique tribuere":84 "e a justiça internacional, prezando taes differenças de facto, na esphera do direito, fará por que os grandes e os pequenos estados, egualmente soberanos, sejam juridicamente eguaes". ${ }^{85}$

Para Pinto Pereira, a sociedade mundial, organizada politicamente, acresce dimensão de direito internacional positivo a esses pressupostos conceituais da igualdade e das regras básicas de convivência entre os estados, no plano internacional: ${ }^{86}$

82 ARRUDA, Braz de Souza. Curso de direito internacional na era atômica. Curitiba - São Paulo - Rio: Guaíra, [19??] - mas, no 'Cavaco', p. 5-11, cit. p. 7-8: "No volume 23 da Revista da Faculdade vem o resumo das minhas prelecções de direito internacional, onde se vê que fui o primeiro a tratar entre nós do direito aéreo e da radiofonia, em suas projecções no campo do direito."

83 PEREIRA, M. F. Pinto. Soberania das nações. Prefácio de Clóvis Bevilaqua. São Paulo: Teixeira, 1920.

84 PEREIRA, M. F. Pinto. Soberania das nações. Prefácio de Clóvis Bevilaqua. São Paulo: Teixeira, 1920. p. 20-21: "Na era do presente, a humanidade delinea, de sob as ruínas de tanta velharia, o arcabouço de um novo edifício. Utilisará, em todo caso, muita coisa do que foi. / Causas geographicas, motivos políticos, particularidades economicas e situações peculiares, embora a mais intima convivência entre as nações, hão de sempre personalisal-as."

85 PEREIRA, M. F. Pinto. Soberania das nações. Prefácio de Clóvis Bevilaqua. São Paulo: Teixeira, 1920. p. 20-21, par. $4^{\circ}$, 'da auto-limitação da soberania', p. 22-27: “Cada qual das nações possue um complexo de bens e de coisas, predicados peculiares; formam-lhe o patrimônio, pertencem-lhe, collocando-a nesta ou naquella situação, para mais ou para menos. O que não pesa no cômputo da independência, que o jus inter gentes lhe reconhece. / Elle as solidarisa, na societas gentium, onde a auto-limitação da soberania nacional é simplesmente a confirmação da personalidade jurídica dos estados livres".

86 PEREIRA, M. F. Pinto. Soberania das nações. Prefácio de Clóvis Bevilaqua. São Paulo: Teixeira, 1920, par. $5^{\circ}$, 'a sociedade mundial, organisada politicamente', p. 28-39: "Da simples sociedade das nações, que é o seu convívio sob o direito internacional, à organisação política da sociedade mundial, vae irreductivel differença. Dissemos: non gentium societas supremae uniuscujusque potestatis negatio implicet, plena ejusdem, autem affirmatio. / Mas, com a organisação política da sociedade mundial, sob a fórma da 'Liga das Nações', impossível é conciliar-se a permanencia da soberania nacional. Aquella organisação, com ser 
organisar o mundo, numa só sociedade politica, é o mais complexo problema, que a mente humana tem concebido, já pela connexão com mil outros difficilimos problemas, já pela chocante desharmonia de outros tantos. É verdade que, nos povos civilisados, são muitas as convergencias de ideaes; não o é menos, todavia, que as divergencias são muitissimas. $^{87}$

42. Dado ser inexorável o imperativo da convivência, a organização desta acarretará limitar o conceito e a extensão do exercício da soberania de cada estado, já percebia M. F. Pinto Pereira (1920):

o estado melhor organisado jamais lograra independencia absoluta, a menos que se isolasse do convivio mundial, e, nesse caso, a sua sorte seria fatalmente o anniquilamento. A comunidade das nações força-as a se darem reciprocamente as mãos e a se fazerem concessões recíprocas; embora em differentes situações políticas, conduz as poderosas a coadjuvarem, no quanto possível, as que o não são. Outro não é o ensinamento dos mestres. (...) Como, apezar do crescente progresso humano, já tantas vezes os interesses vitaes dos povos soberanos se chocaram, ferindo-se guerras, não tenhamos a ingenuidade de descrer que isso possa repetir-se; repetir-se-á, porém, com menor frequencia, si se temperar o conceito de soberania nacional pelo princípio salutar da solidariedade das nações. ${ }^{88}$

política, necessariamente, implica a idéia de um governo universalmente obedecido".

87 PEREIRA, M. F. Pinto. Soberania das nações. Prefácio de Clóvis Bevilaqua. São Paulo: Teixeira, 1920. p. 29, a seguir, p. 35, e, mais adiante, p. 39: "A organisação política da Sociedade das Nações, numa Liga, é um pensamento que não se ajusta com a realidade. Muitos são os mestres que o nutrem; mas, contrariadas pela experiencia, 'as autoridades não valem a menor prova de facto'." (...) "A soberania nacional permanecerá. Com ella é difficilimo o exito da 'Liga das Nações' e absolutamente impossível conciliar-se a organisação política da sociedade mundial".

88 PEREIRA, M. F. Pinto. Soberania das nações. Prefácio de Clóvis Bevilaqua. São Paulo: Teixeira, 1920, p. 45-46, e prossegue, p. 46-47: "A idéia da comunhão do direito, agitada por Savigny no campo do direito internacional privado, e que é hoje um pensamento quase universal, assaz pode concorrer para as solidarisar. É mister que os paizes cultos cooperem para cimentar a sua grande communidade, regida, quando possível for, pelo direito pacifico. / Isso não obsta, bem o vemos, a que a cada qual fique a sua soberania, e como attributo essencial: o que se quer é que ella seja comparticipe activa da solidariedade de todos, na pratica da equidade e da justiça, para a realisação do maior bem commum. A cooperação das grandes e pequenas nações, soberanas e egualmente solidarias, não pede que na vida particular ellas ajam, umas exactamente conforme as outras. / A societas gentium é o ponto em que se hão de converter no bem estar da humanidade os contingentes do trabalho nacional de cada povo. Si circunstancias peculiares vigem, no sentido da differenciação intranacional dos estados, a vida internacional tende a semelhal-os, pela conjugação dos esforços communs em prol de todos. Eis o terreno da cooperação; ella 'supõe a diversidade de meios e simplesmente harmonia de fins'. / A verdadeira solidariedade das nações soberanas consiste no promoverem, sobre tudo, a justiça nas suas relações, obedecidas as sentenças dos tribunaes, que proclamam o direito, tendo-se a força armada como o extremo recurso no solucionar das pendências." 
43. Voltam a aparecer, respectivamente, os nomes de Braz Arruda e Sampaio Dória, em 1941, e assim permanecem, até 1945.

Em 1946, permanece Braz Arruda e ao lado deste, para o direito internacional privado "programa do Prof. Dr. Antonio de Sampaio Dória adotado pelo livre-docente Dr. Luís Antonio da Gama e Silva". ${ }^{89}$ Repete-se a formulação, de 1948 até 1952.90

44. De 1955 até 1963, os programas de direito internacional público e privado serão apresentados, respectivamente, por Braz Arruda e Gama e Silva (19131979).

Em 1964 e 1965, em relação ao direito internacional público, consta o “programa do Prof. Braz de Souza Arruda, adotado pelo Dr. Vicente Marotta Rangel, na regência da cátedra". ${ }^{91}$ De 1966 em diante Vicente Marotta Rangel rege a cátedra de direito internacional público.

45. Na cátedra de direito internacional privado, Gama e Silva, ${ }^{92}$ depois de a exercer por vinte anos, será também o diretor da escola, por duas vezes foi reitor da Universidade de São Paulo e ministro da justiça. Será sucedido por Irineu Strenger (19232007), que a exercerá a titularidade de direito internacional privado, por vinte anos, de 1971 a $1991 . .^{93}$

89 Não há exemplar de Anuário para 1947.

90 Não há exemplar de Anuários para 1953 e 1954.

91 Não há exemplar de Anuário para 1967.

92 SILVA, Luis Antonio da Gama e. As qualificações em direito internacional privado. 1952. Monografia (Concurso à cátedra de Direito Internacional Privado) - Faculdade de Direito, Universidade de São Paulo, São Paulo, 1952.

93 STRENGER, Irineu. Teoria geral do direito internacional privado. São Paulo: José Bushatsky, 1973; STRENGER, Irineu. Arbitragem comercial internacional. São Paulo: LTr, 1996.; STRENGER, Irineu. Prefácio. In: CASELLA, Paulo Borba. Comunidade européia e seu ordenamento jurídico. 1. ed. São Paulo: LTr, 1994 e 2. ed. 2002; STRENGER, Irineu. Temas de formação filosófica. São Paulo: Revista dos Tribunais, 1986. 158 p.; STRENGER, Irineu. Da autonomia da vontade em direito internacional privado. 1967. 230 p. Tese (Livre-docência em Direito Internacional) - Faculdade de Direito, Universidade de São Paulo, São Paulo, 1967. 230 p., depois publicada, com o mesmo título (São Paulo: Revista dos Tribunais, 1968); STRENGER, Irineu. Regime jurídico da reparação do dano em direito internacional privado. 1971. 275 p. Tese (Titular em Direito Internacional Privado) - Faculdade de Direito, Universidade de São Paulo, São Paulo, 1971; depois publicada, Reparação do dano em direito internacional privado. Prefácio de Amílcar de Castro. São Paulo: Revista dos Tribunais, 1973; STRENGER, Irineu. Direito internacional privado: parte geral, direito civil internacional, direito comercial internacional. 1. ed. São Paulo: Revista dos Tribunais, 1986. (4. ed., aumentada e atualizada, S. Paulo: LTr, 2000); STRENGER, Irineu. Mandado de injunção. Prefácio de J. Cretella Jr. Rio de Janeiro: Forense Universitária, 1988; Strenger foi responsável pela revisão terminológica da tradução do volume LESGUILLONS, Henry. (Org.). As garantias bancárias nos contratos internacionais. São Paulo: Saraiva, 1985; STRENGER Irineu. Direito moderno em foco: responsabilidade civil, direito marítimo, direito internacional privado, direito comparado, teoria geral do direito. São Paulo: Revista dos Tribunais, 1986, ("prefácio"): "O Direito moderno em foco é, precisamente, captação dos principais elementos que hoje conduzem o direito a novos rumos, em vários campos da fenomênica jurídica, entre os quais despontam os temas da responsabilidade civil, o direito marítimo, e alguns importantes aspectos legais do dinheiro, tão bem assinalados por Paulo Borba Casella, cuja contribuição se encontra em anexo deste livro"; STRENGER, Irineu. Contratos internacionais do 
Na cadeira de direito internacional privado, será sucedido por João Grandino Rodas, ${ }^{94}$ que também foi diretor da escola, de 2006 a 2010, e reitor da Universidade de São Paulo, de 2010 a 2014.

46. Vicente Marotta Rangel(1924-2017), bacharel em direito pela Faculdade de Direito da Universidade de São Paulo, em 1946, doutor em direito internacional pela Universidade de Paris, em 1950, ${ }^{95}$ livre-docente em direito internacional, com tese Do conflito entre a carta das Nações Unidas e os demais acordos internacionais (1954), ${ }^{96}$ tornou-se catedrático de direito internacional público, com tese sobre Natureza jurídica e delimitação do mar territorial (1964, segunda edição, revista, 1970) ${ }^{97}$ regeu essa cátedra de 1966, até se aposentar em 1994.

Marotta Rangel ministrou curso na Academia de direito internacional, na Haia, sobre A plataforma continental na Convenção de 1982 sobre o direito do mar (1985). ${ }^{98}$ A sua extensa e relevante produção ${ }^{99}$ se soma o papel destacado, no cenário

comércio. Prefácio L. G. Paes de Barros Leães. 1. ed. São Paulo: Revista dos Tribunais, 1986; 2. ed., rev. e ampliada, 1992; BAPTISTA, Luis Olavo; HUCK, Hermes Marcelo; CASELLA, Paulo Borba (Orgs.). Direito e comércio internacional: tendências e perspectivas - estudos em homenagem a Irineu Strenger. São Paulo: LTr, 1994; STRENGER, Irineu. La notion de lex mercatoria en droit du commerce international. Recueil des Cours de l'Académie de Droit International, Leinden/Boston, v. 227, p. 207-356, 1991; e tb. Direito do comércio internacional e lex mercatoria. Pref. Fábio Konder Comparato. São Paulo: LTr, 1996.

94 RODAS, João Grandino; MÔNACO, Gustavo Ferraz de Campos. A Conferência da Haia de direito internacional privado: a participação do Brasil. Brasília: Fundação Alexandre Gusmão, 2007; RODAS, João Grandino; OLIVEIRA, Gesner. Direito e economia da concorrência. Rio de Janeiro: Renovar, 2004; RODAS, João Grandino. (Coord.). Contratos internacionais. 3. ed. rev., atual. e ampl. São Paulo: Revista dos Tribunais, 2002; RODAS, João Grandino. Sociedade comercial e estado. Prefácio Fábio Konder Comparato. São Paulo: UNESP: Saraiva, 1995; RODAS, João Grandino. A nacionalidade da pessoa física no Brasil, após 1988. In: BAPTISTA, Luis Olavo; HUCK, Hermes Marcelo; CASELLA, Paulo Borba (Orgs.). Direito e comércio internacional: tendências e perspectivas - estudos em homenagem a Irineu Strenger. São Paulo: LTr, 1994. p. 221-241; RODAS, João Grandino. Direito internacional privado brasileiro. São Paulo: Revista dos Tribunais, 1993; RODAS, João Grandino. Choice of law rules and the major principles of Brazilian private international law. In: DOLINGER, Jacob; ROSENN, Keith S. (Ed.). A panorama of Brazilian Law. Coral Gables, Fla.: published jointly by the North-South Center and Editora Esplanada Ltda., 1992. p. 309-347; RODAS, João Grandino. A nacionalidade da pessoa fisica. São Paulo: Revista dos Tribunais, 1990.

95 Auxiliar de ensino em 15 de setembro de 1954; livre-docente em 28 de junho de 1955; professor assistente contratado em $1^{\circ}$ de janeiro de 1960; professor assistente nomeado em 26 de março de 1965; rege a cadeira, interinamente, bem como o curso de organizações internacionais a partir de outubro de 1965. Acede à cátedra em 1966.

96 RANGEL, Vicente Marotta. Do conflito entre a carta das Nações Unidas e os demais acordos internacionais. São Paulo: Saraiva, 1954.

97 RANGEL, Vicente Marotta. Natureza jurídica e delimitação do mar territorial. 2. ed. rev. São Paulo: Revista dos Tribunais, [1970].

98 RANGEL, Vicente Marotta. Le plateau continental dans la Convention de 1982 sur le droit de la mer. Recueil des Cours de l'Académie de Droit International, Leinden/Boston, v. 194, p. 273-427, 1985.

99 RANGEL, Vicente Marotta. Direito e relações internacionais. 8. ed. São Paulo: Revista dos Tribunais, 2005; RANGEL, Vicente Marotta. L'avis consultatif du 9 juillet 2004 et l'antinomie entre volontarisme et solidarisme. In: DEGAN, Vladimir-Đjuro; CRNIĆ-GROTIĆ, Vesna. International law and the use of force at the turn of centuries: essays in honour of V. Đjuro Degan. Rijeka: Faculty of Law, Univ. of Rijeka, 2005, 
nacional ${ }^{100}$ e internacional, como Juiz do Tribunal internacional para o direito do mar, em Hamburgo, desde 1996, e o levaram a ser distinguido com os títulos de doutor honoris causa, pela Faculdade de Direito da Universidade de Coimbra, em 2000, bem como de professor emérito, concedido pela Congregação da Faculdade de Direito da Universidade de São Paulo, em 2006. Em 2015 foi homenageado ${ }^{101}$ e faleceu em 2017.

47. Guido Fernando da Silva Soares (1937-2005) realiza seus estudos de "ciências jurídicas e sociais" na Faculdade de Direito da USP (1955-1959) e a seguir estudos de especialização (1960-1963) no Instituto Rio Branco, no Rio de Janeiro, para ingressar no serviço diplomático. Torna-se segundo secretário, em 1963, e serve nas Embaixadas do Brasil em Moscou e em Montevidéu.

Em 1970, retorna ao Brasil e ingressa no quadro docente da Pontifícia Universidade Católica de São Paulo, ao mesmo tempo em que enceta o doutorado em ciências humanas e a pós-graduação da Faculdade de Direito da USP. Cursa mestrado em direito comparado na Faculdade de Direito da Universidade de Illinois (1974-1975).

48. Doutora-se na PUC com a tese Contribuição ao estudo da política nuclear brasileira (1975) e é aprovado em concurso de livre-docência na Faculdade de Direito da USP, com tese sobre Das imunidades de execução e jurisdição (1980).

Em 1993 se vê reintegrado ao serviço diplomático. Vence concurso de titularidade para a cadeira de direito internacional público, com tese sobre $A s$

p. 199-205. Cap. 10; RANGEL, Vicente Marotta. A experiência da conferência da ONU e a Convenção sobre direito do mar. In: NAZO, Georgette Nacarato (Coord.). Questões importantes referentes ao mar. São Paulo: Soamar, 1996. p. 11-18; RANGEL, Vicente Marotta. Objetos culturais: o recente projeto UNIDROIT de convenção internacional. In: BAPTISTA, Luis Olavo; HUCK, Hermes Marcelo; CASELLA, Paulo Borba (Orgs.). Direito e comércio internacional: tendências e perspectivas - estudos em homenagem a Irineu Strenger. São Paulo: LTr, 1994. p. 213-220; RANGEL, Vicente Marotta. Sobre la efectividad de la justicia en las relaciones internacionales. In: Rama Montaldo, Manuel et al. El derecho internacional en un mundo en transformación: liber amicorum en homenaje al profesor Eduardo Jiménez de Aréchaga. Montevideo: Fundación de Cultura Universitaria, 1994; RANGEL, Vicente Marotta. Public international law: the last five decades. In: DOLINGER, Jacob; ROSENN, Keith (Ed.). A panorama of Brazilian Law. Miami / Rio de Janeiro: Univ. of Miami North-South Center / Ed. Esplanada, 1992. p. 287-308; RANGEL, Vicente Marotta. L'equité en droit international: des développements récents. Tessaloniki: Aristoteleio Panepistimio «Nomos», «Anatypo»: separata, 1989. p. 937-950; RANGEL, Vicente Marotta. O direito do mar e a sua unificação legislativa entre países de língua portuguesa. In: Estudos em homenagem ao professor A. FerrerCorreia. Coimbra: Univ. de Coimbra, 1986. v. 1, p. 69-90; RANGEL, Vicente Marotta. Solução pacífica de controvérsias. In: COMITÊ JURÍDICO INTERAMERICANO (Org.). XI Curso de derecho internacional. Cooperación de la Secretaria general de la OEA, Rio de Janeiro, agosto de 1984. Washington: O.E.A.Secretaria General, 1985. p. 29-48.

100 BAPTISTA, Luiz Olavo; FONSECA, José Roberto Franco da. (Coord.). O direito internacional no terceiro milênio: estudos em homenagem a Vicente Marotta Rangel. São Paulo: LTr, 1998. esp. p. 17-24, para as referências biobibliográficas.

101 CASELLA, Paulo Borba. Vicente Marotta Rangel - vida e obra. Direito internacional nas Arcadas. Revista da Faculdade de Direito da Universidade de São Paulo, São Paulo, v. 110, p. 19-53, jan./dez. 2015. 
responsabilidades no direito internacional do meio ambiente (1995), ${ }^{102}$ e toma posse da cadeira em 1998, da qual se afasta no final de 2004, e vem a falecer em 2005. Foi homenageada a sua memória com coletânea de estudos. ${ }^{103}$

\section{Desde 2005 rege os cursos de direito internacional público Paulo Borba}

Casella. Em $1^{\circ}$ de junho de 2007 vence, por quatro votos, o concurso para professor titular de direito internacional público da Faculdade de Direito da USP, com tese sobre Fundamentos do direito internacional pós-moderno (tese 2006), ${ }^{104}$ edição comercial $(2008)^{105}$ e toma posse da cadeira, em 28 de fevereiro de 2008.

Depois de cursar a graduação em direito (1978-1982) na Universidade de

São Paulo, doutorou-se Paulo Casella em direito internacional (1986), ${ }^{106}$ fez pós-doutorado

102 A tese de concurso de Guido Fernando da Silva Soares foi publicada sob o título Direito internacional do meio ambiente: emergência, obrigações e responsabilidades. São Paulo: Atlas, 2001.

103 CASELLA, Paulo Borba et al (Org.). Direito internacional, humanismo e globalidade: Guido Fernando Silva SOARES: amicorum discipulorum líber. São Paulo: Atlas, 2008.

104 P. B. Casella, Fundamentos do direito internacional pós-moderno inovam no enfoque dado ao conjunto dos temas centrais da disciplina, contextualizados no mundo atual, ante a necessidade de responder ao desafio da pós-modernidade, que se põe para o direito como um todo, e nela se analisa em relação ao direito internacional: enfatiza a necessidade dos princípios, normas e procedimentos de direito internacional, não somente como ferramentas da paz e da segurança internacionais, mas como condições para a sobrevivência da humanidade, em mundo no qual a capacidade tecnológica de causar a destruição da vida e da civilização no planeta desenvolveu-se muito mais do que os mecanismos institucionais para garantir a paz: o quadro apresenta riscos e as ameaças são presentes e relevantes, mas a convicção da possibilidade de aperfeiçoamento das instituições e das normas internacionalmente indispensáveis são o modo melhor e mais seguro de garantir os fundamentos do direito internacional pós-moderno - para esta e as próximas gerações. Cumpre ressaltar a abrangência do enfoque a pertinência, para tese de titularidade em direito internacional público, pela atualidade com a qual são tratados os temas como a questão do uso da força, da construção dos princípios, da evolução da jurisprudência internacional, da codificação do direito internacional e da consolidação das normas cogentes de direito internacional (jus cogens), bem como por situar a necessidade e o papel das instituições e do direito internacional, na ordenação das relações e da vida internacionais.

105 A tese de concurso de P. B. Casella, CASELLA, Paulo Borba. Fundamentos do direito internacional pósmoderno. 2006 se publica com o mesmo título (prólogo de Hugo Caminos, São Paulo: Quartier Latin, 2008), compunha-se de 1.536 páginas, em formato $16 \times 23 \mathrm{~cm}$, e contém os itens seguintes: introdução, construção do direito internacional e contexto pós-moderno (i), precisões terminológicas e valorativas (ii), direito internacional pós-moderno: entre técnica, espírito e utopia (iii), sujeito e objeto: estado de natureza, natureza do estado e relações entre estados (iv), direito internacional e duração (v), direito, história e cultura (vi), eunomia internacional (vii), questão e discurso do fundamento do direito internacional (viii), fundamento e norma cogente de direito internacional (ix), opinio iuris e corte epistemológico - entre conceitos universais e expedientes específicos: princípios, valores e regras (x), creatio ex nihilo: justiça e força (xi), direito e relações internacionais: coexistência pacífica? (xii), boa tradição e a que se deve evitar (xiii), contendo análise do direito internacional no Brasil e das relações exteriores do Brasil, bom e justo no contexto econômico e no direito internacional (xiv), contingência e uso da força no direito internacional (xv), jurisdição, competência do estado e aplicação do direito internacional (xvi), política e moral (xvii), conclusão, abreviaturas, bibliografia, textos e fontes de consulta eletrônica, jurisprudência internacional: pareceres consultivos e casos julgados C.P.J.I. e C.I.J., resoluções e votos do Instituto de direito internacional e índice remissivo.

106 A tese de doutoramento em direito internacional de P. B. Casella, Apoderamento ilícito de aeronaves (1986) teve edição revista e atualizada, sob o título, Direito internacional, terrorismo e aviação civil. São Paulo: Quartier Latin, 2006. 
na Universidade de Paris X - Nanterre (1987), livre-docência em direito internacional (1993), ${ }^{107}$ na Faculdade de Direito da USP, onde leciona direito internacional desde 1984. Presidente da Comissão de Publicação da Revista da Faculdade de Direito, tendo sido chefe do Departamento de direito internacional e comparado (2008-2010), vice-diretor da Faculdade (2010-2014) e exercido outros dois mandatos como chefe do Departamento de direito internacional e comparado (2014-2016 e 2016-2018).

50. Aos Fundamentos do direito internacional pós-moderno (2008) seguiram-se o Direito internacional dos espaços $(2009)^{108}$ e os volumes dedicados ao Direito internacional no tempo antigo (2012), Direito internacional no tempo medieval e moderno até Vitoria (2012), Direito internacional no tempo moderno de Suarez a Grócio (2014), Direito internacional no tempo clássico (2015), Direito internacional no tempo do Iluminismo (2017), ${ }^{109}$ bem como artigos e capítulos em obras coletivas, publicados em vários países.

51. Longo o caminho percorrido pelo ensino do direito internacional em nossa escola, desde a aula inaugural de Brotero em 1828, até o momento presente, em que se comemoram os 190 anos: o leque de matérias se amplia, a internacionalização da vida, no contexto pós-moderno sequer precisa ser enfatizada - todos percebem isso.

De ponto de vista organizacional tornou-se a antiga cátedra todo um departamento de direito internacional, e este tem caráter único, enquanto núcleo, institucionalmente organizado, de pesquisadores e docentes, no país, nas áreas do direito internacional público, direito internacional privado e direito do comércio internacional e direito comparado. É preciso que se tenha consciência da importância desse conjunto, para que se pense e se opere como equipe, e não a mera somatória de projetos individuais paralelos.

52. Em 2008, passa a ser o nosso "Departamento de direito internacional e comparado". Esta missão se agrega ao conjunto, como proposta de ênfase na formação ampla e na perspectiva culturalmente abrangente, para a docência e a pesquisa destes campos do saber jurídico. ${ }^{110}$

107 A tese de livre-docência em direito internacional de P. B. Casella, Elementos de direito comunitário (1993) foi publicada sob o título Comunidade européia e seu ordenamento jurídico. Prefácio de Irineu Strenger. São Paulo: LTr, 1994 e a segunda edição, substancialmente revista e ampliada União Européia: instituições e ordenamento jurídico. São Paulo: LTr, 2002.

108 CASELlA, Paulo Borba. Direito internacional dos espaços. São Paulo: Atlas, 2009.

109 CASELlA, Paulo Borba. Direito internacional no tempo antigo. São Paulo: Atlas, 2012; Direito internacional no tempo medieval e moderno até Vitoria. São Paulo: Atlas, 2012; CASELLA, Paulo Borba. Direito internacional no tempo moderno de Suarez a Grócio. São Paulo: Atlas, 2014; CASELLA, Paulo Borba. Direito internacional no tempo clássico. São Paulo: Atlas, 2015. No prelo, o Direito internacional no tempo do Iluminismo, 2017.

110 Ver VIDIGAL, Allan. Faculdade de Direito do Largo de São Francisco: USP 190 anos. Prefácio de José Rogério Cruz e Tucci. São Paulo: DBA., 2017, esp. 'Departamento de direito internacional e comparado 
A construção de escola de direito internacional nas Arcadas se fez ao longo destes 190 anos, transcorridos desde a lição inaugural de Avelar Brotero, em $1^{\circ}$. de março de 1828. As lições a serem extraídas dessa trajetória são múltiplas e são muito ricas. ${ }^{111}$

Ao mesmo tempo em que nos cumpre refletir sobre o legado dos que nos precederam, cabe ter presente a extensão das tarefas novas, onde se projetam os desafios e as necessidades para o direito internacional, no contexto da pós-modernidade.

Arcadas, 17 VIII 2017.

\section{Referências}

ACCIOLY, Hildebrando Pompeo Pinto; SILVA, Geraldo Eulálio do Nascimento e; CASELLA, Paulo Borba. Manual de direito internacional público. 23. ed. São Paulo: Saraiva, 2017.

ANZILOTTI, Dionisio. Cours de droit international. Traduction Française par Gilbert Gidel. Paris: LGDJ, 1999.

ARRUDA, Braz de Souza. Curso de direito internacional na era atômica. Curitiba - São Paulo Rio: Guaíra, [19??].

BAPTISTA, Luiz Olavo; FONSECA, José Roberto Franco da. (Coord.). O direito internacional no terceiro milênio: estudos em homenagem a Vicente Marotta Rangel. São Paulo: LTr, 1998.

BAPTISTA, Luiz Olavo; HUCK, Hermes Marcelo; CASELLA, Paulo Borba. (Coord.). Direito e comércio internacional: tendências e perspectivas: estudos em homenagem ao Prof. Irineu Strenger. São Paulo: LTr, 1994.

BELLO, Andrés. Derecho internacional. Caracas: Ed. del Ministerio de Educación, 1954. (I. Principios de derecho internacional y escritos complementarios; v. 10).

BELLO, Andrés. Derecho internacional. Caracas: Ed. del Ministerio de Educación, 1959. (II. Temas de política internacional; v. 11).

BELLO, Andrés. Gramática de la lengua castellana destinada al uso de los americanos. Madri: EDAF, 1984.

BELLO, Andrés. Principios de derecho de gentes. Sucre: Imprenta de Beeche y Compañia, 1844.

(DIN)', p. 71-75.

111 CASELLA, Paulo Borba. Abz: ensaios didáticos. Prefácio de João Grandino Rodas. São Paulo: Imprensa Oficial do Estado, 2008, "Faculdade enquanto possibilidade - o papel do Largo de São Francisco". Parte desse debate se fez e se faz no largo de São Francisco. Por isso pode ser relevante ter consciência do que representa a escola, para o país, e pode representar para a vida, de cada um dos que tem a oportunidade e a responsabilidade de participar dela. 
BROTERO, Frederico de Barros. Traços biográficos do Conselheiro José Maria Avelar Brotero, por seu neto. São Paulo: [s.n.], 1933.

BROTERO, José Maria de Avelar. A filosofia do direito constitucional. Introdução de José Afonso da Silva. São Paulo: Malheiros, 2007.

BROTERO, José Maria de Avelar. Princípios de direito natural. Rio de Janeiro: Typografia Imperial e Nacional, 1829.

BROTERO, José Maria de Avelar. Questões sobre presas marítimas. 2. ed augmentada. São Paulo: Typographia - imparcial - de J. R. de Azevedo Marques, 1863.

BROTERO, José Maria de Avelar. Questões sobre presas maritimas: Offerecidas ao cidadão Rafael Tobias de Aguiar. São Paulo: Typ. Costa Silveira, 1836.

CAPOTORTI, Francesco. Cours général de droit international public. Recueil des Cours de l'Académie de Droit International, Leinden/Boston, v. 248, p. 9-344, 1994.

CASELLA, Paulo Borba et al (Org.). Direito internacional, humanismo e globalidade: Guido Fernando Silva Soares: amicorum discipulorum líber. São Paulo: Atlas, 2008.

CASELLA, Paulo Borba. Abz: ensaios didáticos. Prefácio de João Grandino Rodas. São Paulo: Imprensa Oficial do Estado, 2008.

CASELLA, Paulo Borba. Apoderamento ilícito de aeronaves. 1986. Tese (Doutorado) - Faculdade de Direito, Universidade de São Paulo, São Paulo, 1986.

CASELLA, Paulo Borba. Cem anos do Direito Internacional Público (1913) de José Mendes (18611918): olhar reflexivo sobre o Direito Internacional nas Arcadas (1911-1918). Revista da Faculdade de Direito da Universidade de São Paulo, São Paulo, v. 108, p. 27-44, jan./dez. 2013.

CASELLA, Paulo Borba. Comunidade européia e seu ordenamento jurídico. São Paulo: LTr, 1994.

CASELLA, Paulo Borba. Direito internacional dos espaços. São Paulo: Atlas, 2009.

CASELLA, Paulo Borba. Direito internacional nas arcadas: a aula inaugural de 16 de fevereiro de 2009. Revista da Faculdade de Direito da Universidade de São Paulo, São Paulo, v. 104, p. 931966, jan./dez. 2009.

CASELLA, Paulo Borba. Direito internacional no tempo antigo. São Paulo: Atlas, 2012.

CASELLA, Paulo Borba. Direito internacional no tempo clássico. São Paulo: Atlas, 2015.

CASELLA, Paulo Borba. Direito internacional no tempo do Iluminismo (no prelo, 2017).

CASELLA, Paulo Borba. Direito internacional no tempo medieval e moderno até Vitoria. São Paulo: Atlas, 2012.

CASELLA, Paulo Borba. Direito internacional no tempo moderno de Suarez a Grócio. São Paulo: Atlas, 2014. 
CASELLA, Paulo Borba. Direito internacional, terrorismo e aviação civil. São Paulo: Quartier Latin, 2006.

CASELLA, Paulo Borba. Direito internacional, vida e memória de Irineu Strenger (1923-2007). Revista de Arbitragem e Mediação, São Paulo, v. 4, n. 15, p. 11-18, out./dez. 2007.

CASELlA, Paulo Borba. Elementos de direito comunitário. 1993. Tese (Livre Docência) Faculdade de Direito, Universidade de São Paulo, São Paulo, 1993.

CASELLA, Paulo Borba. Fundamentos do direito internacional pós-moderno. São Paulo: Quartier Latin, 2008.

CASELLA, Paulo Borba. Fundamentos do direito internacional pós-moderno. 2006. Tese (Professor Titular) - Faculdade de Direito, Universidade de São Paulo, São Paulo, 2006.

CASELLA, Paulo Borba. ONU pós-KELSEN. In: MERCADANTE, Araminta de Azevedo; MAGALHÃES, José Carlos de. (Org.). Reflexões sobre os 60 anos da ONU. Ijuí: Editora Unijuí, 2005. p. 13-64.

CASELLA, Paulo Borba. União Européia: instituições e ordenamento jurídico. São Paulo: LTr, 2002.

CASELLA, Paulo Borba. Vicente Marotta Rangel - vida e obra. Direito internacional nas Arcadas. Revista da Faculdade de Direito da Universidade de São Paulo, São Paulo, v. 110, p. 19-53, jan./ dez. 2015.

CAVAGLIERI, Arigo. Règles générales du droit de la paix. Recueil des Cours de l'Académie de Droit International, Leinden/Boston, v. 26, p. 311-586, 1929.

CENTRO DE DOCUMENTAÇÃO DO PENSAMENTO BRASILEIRO. Dicionário biobibliográfico de autores brasileiros. Salvador: CDPB; Brasília: Senado Federal, 1999.

CHARVIN, Robert. Le droit international tel qu'il a été enseigné. Notes critiques de lecture des traités et des manuels (1850-1950). In: CHAUMONT, Charles. Le droit des peuples à disposer d'eux-mêmes: méthodes d'analyse du droit international. Mélanges offerts à Charles Chaumont. Paris: Pedone, 1984.

CHAUMONT, Charles. Cours général de droit international public. Recueil des Cours de l'Académie de Droit International, Leinden/Boston, v. 129, p. 333-528, 1970.

COSTA, José da Silva. Carta do eminente jurisconsulto. In: MENDES, José. Ensaios de filosofia do direito. São Paulo: Duprat, 1905.

FACULDADE DE DIREITO DE S. PAULO. Memória histórica acadêmica de 1877. São Paulo: [s.n.], 1878. p. 2.

FERREIRA, Waldemar. A Congregação da Faculdade de Direito de São Paulo na centuria de 1827 a 1927. Revista da Faculdade de Direito de São Paulo, São Paulo, v. 24, jan./dez. 1928. 
HEILBORN, Paul. Les sources du droit international. Recueil des Cours de l'Académie de Droit International, Leiden/Boston, v. 11, p. 1-64, 1926.

KOSKENNIEMI, Martti. The gentle civilizer of nations: the rise and fall of international law 18701960. Cambridge: Cambridge University Press, 2005.

LAGHMANI, Slim. Histoire du droit des gens: du jus gentium impérial au jus publicum europaeum. Paris: Pedone, 2003.

LESGUILLONS, Henry. (Org.). As garantias bancárias nos contratos internacionais. São Paulo: Saraiva, 1985.

MELO, Luís Correia de. Dicionário de autores paulistas. São Paulo: Comissão do IV Centenário da Cidade de São Paulo, 1954.

MENDES, José. Das servidões de caminho: direito romano e pátrio. São Paulo: Duprat \& Cia., 1906.

MENDES, José. Direito internacional publico: prelecções. São Paulo: Duprat \& Comp., 1913.

MENDES, José. Ensaios de philosophia do direito. Edição do autor. São Paulo: Duprat \& Cia., 1905. $2 \mathrm{v}$.

MENDES, José. Relação entre o direito internacional publico e o direito nacional nos paizes americanos. Revista dos Tribunaes, São Paulo, v. 24, p. 81, 1917.

MOORE, John Bassett. Digest of international law. Washington: Government Priting Office, 1860. $8 \mathrm{v}$.

NOGUEIRA, José Luís de Almeida. A academia de São Paulo: tradições e reminiscências: estudantes, estudantões, estudantadas: edição comemorativa do sesquicentenário dos cursos jurídicos no Brasil, 1827-1977. 3. ed. São Paulo: Saraiva, 1977. v. 1-3.

ONUMA Yasuaki. Le droit international et le Japon: une vision transcivilisationnelle du monde. Préface de Mireille Delmas-Marty. Paris: Pedone, 2016.

ONUMA, Yasuaki. Direito internacional em perspectiva transcivilizacional: questionamento da estrutura cognitiva predominante no emergente mundo multipolar e multicivilizacional do século XXI. Tradução Alan Carvalho et al., org. da tradução e apresentação de Masato Ninomiya e Paulo Borba Casella. Belo Horizonte: Arraes Editores, 2017.

PEREIRA, M. F. Pinto. Soberania das nações. Prefácio de Clóvis Bevilaqua. São Paulo: Teixeira, 1920.

RANGEL, Vicente Marotta. A experiência da conferência da ONU e a Convenção sobre direito do mar. In: NAZO, Georgette Nacarato (Coord.). Questões importantes referentes ao mar. São Paulo: Soamar, 1996. 
RANGEL, Vicente Marotta. Direito e relações internacionais. 8. ed. São Paulo: Revista dos Tribunais, 2005.

RANGEL, Vicente Marotta. Do conflito entre a carta das Nações Unidas e os demais acordos internacionais. São Paulo: Saraiva, 1954.

RANGEL, Vicente Marotta. L'avis consultatif du 9 juillet 2004 et l'antinomie entre volontarisme et solidarisme. In: DEGAN, Vladimir-Đjuro; CRNIĆ-GROTIĆ, Vesna. International law and the use of force at the turn of centuries: essays in honour of V. Đjuro Degan. Rijeka: Faculty of Law, Univ. of Rijeka, 2005, p. 199-205. Cap. 10.

RANGEL, Vicente Marotta. L'equité en droit international: des développements récents. Tessaloniki: Aristoteleio Panepistimio «Nomos», «Anatypo»: separata, 1989. p. 937-950.

RANGEL, Vicente Marotta. Le plateau continental dans la Convention de 1982 sur le droit de la mer. Recueil des Cours de l'Académie de Droit International, Leinden/Boston, v. 194, p. 273-427, 1985.

RANGEL, Vicente Marotta. Natureza jurídica e delimitação do mar territorial. 2. ed. rev. São Paulo: Revista dos Tribunais, [1970].

RANGEL, Vicente Marotta. O direito do mar e a sua unificação legislativa entre países de língua portuguesa. In: Estudos em homenagem ao professor A. Ferrer-Correia. Coimbra: Univ. de Coimbra, 1986. v. 1, p. 69-90.

RANGEL, Vicente Marotta. Objetos culturais: o recente projeto UNIDROIT de convenção internacional. In: BAPTISTA, Luis Olavo; HUCK, Hermes Marcelo; CASELLA, Paulo Borba (Orgs.). Direito e comércio internacional: tendências e perspectivas - estudos em homenagem a Irineu Strenger. São Paulo: LTr, 1994. p. 213-220.

RANGEL, Vicente Marotta. Public international law: the last five decades. In: DOLINGER, Jacob; ROSENN, Keith (Ed.). A panorama of Brazilian Law. Miami / Rio de Janeiro: Univ. of Miami North-South Center / Ed. Esplanada, 1992. p. 287-308.

RANGEL, Vicente Marotta. Sobre la efectividad de la justicia en las relaciones internacionales. In: RAMA MONTALDO, Manuel et al. El derecho internacional en un mundo en transformación: liber amicorum en homenaje al profesor Eduardo Jiménez de Aréchaga. Montevideo: Fundación de Cultura Universitaria, 1994.

RANGEL, Vicente Marotta. Solução pacífica de controvérsias. In: COMITÊ JURÍDICO INTERAMERICANO (Org.). XI Curso de derecho internacional. Cooperación de la Secretaria general de la OEA, Rio de Janeiro, agosto de 1984. Washington: O.E.A.- Secretaria General, 1985. p. 29-48.

REALE, Miguel. Avellar Brotero, ou a ideologia sob as Arcadas. In: REALE, Miguel. Filosofia em São Paulo, 1 ed. São Paulo: Grijalbo, 1962. 
REALE, Miguel. Avellar Brotero, ou a ideologia sob as Arcadas. In: REALE, Miguel. Filosofia em São Paulo, 2 ed. rev. e reestruturada. São Paulo: EDUSP/Grijalbo, 1976. p. 63-91.

REALE, Miguel. Avellar Brotero, ou a ideologia sob as Arcadas. In: Horizontes do direito e da história: estudos de filosofia do direito e da cultura. São Paulo: Saraiva, 1956. p. 195-224.

RODAS, João Grandino. (Coord.). Contratos internacionais. 3. ed. rev., atual. e ampl. São Paulo: Revista dos Tribunais, 2002.

RODAS, João Grandino. A nacionalidade da pessoa física no Brasil, após 1988. In: BAPTISTA, Luis Olavo; HUCK, Hermes Marcelo; CASELLA, Paulo Borba (Orgs.). Direito e comércio internacional: tendências e perspectivas - estudos em homenagem a Irineu Strenger. São Paulo: LTr, 1994. p. 221-241.

RODAS, João Grandino. A nacionalidade da pessoa física. São Paulo: Revista dos Tribunais, 1990. RODAS, João Grandino. Choice of law rules and the major principles of Brazilian private international law. In: DOLINGER, Jacob; ROSENN, Keith S. (Ed.). A panorama of Brazilian Law. Coral Gables, Fla.: published jointly by the North-South Center and Editora Esplanada Ltda., 1992. p. 309-347.

RODAS, João Grandino. Direito internacional privado brasileiro. São Paulo: Revista dos Tribunais, 1993.

RODAS, João Grandino. Sociedade comercial e estado. Prefácio Fábio Konder Comparato. São Paulo: UNESP: Saraiva, 1995.

RODAS, João Grandino; MÔNACO, Gustavo Ferraz de Campos. A Conferência da Haia de direito internacional privado: a participação do Brasil. Brasília: Fundação Alexandre Gusmão, 2007.

RODAS, João Grandino; OLIVEIRA, Gesner. Direito e economia da concorrência. Rio de Janeiro: Renovar, 2004.

RODRIGUES, Horácio Wanderlei. Novo currículo mínimo dos cursos jurídicos. São Paulo: Revista dos Tribunais, 1995.

SETTE-CAMARA, José. Pollution of international rivers. Recueil des Cours de l'Académie de Droit International, Leinden/Boston, v. 186, p. 117-218, 1984.

SETTE-CÂMARA, José. Poluição de rios internacionais. Tradução e posfácio de Arthur Roberto Capella Giannattasio, Coordenação da edição brasileira e prefácio de Paulo Borba Casella. São Paulo: Quartier Latin, 2011.

SILVA, Luis Antonio da Gama e. As qualificações em direito internacional privado. 1952. Monografia (Concurso à cátedra de Direito Internacional Privado) - Faculdade de Direito, Universidade de São Paulo, São Paulo, 1952. 
SNYDER. Timothy. Sobre a tirania: vinte lições do século XX para o presente. São Paulo: Companhia das Letras, 2017.

SOARES, Guido Fernando Silva. Curso de direito internacional público. São Paulo: Atlas, 2002. v. 1.

SOARES, Guido Fernando Silva. Direito internacional do meio ambiente: emergência, obrigações e responsabilidades. São Paulo: Atlas, 2001.

STRENGER Irineu. Direito moderno em foco: responsabilidade civil, direito marítimo, direito internacional privado, direito comparado, teoria geral do direito. São Paulo: Revista dos Tribunais, 1986.

STRENGER, Irineu. Arbitragem comercial internacional. São Paulo: LTr, 1996.

STRENGER, Irineu. Contratos internacionais do comércio. Prefácio L. G. Paes de Barros Leães. 1. ed. São Paulo: Revista dos Tribunais, 1986. (2. ed., rev. e ampliada, 1992).

STRENGER, Irineu. Da autonomia da vontade em direito internacional privado. 1967. 230 p. Tese (Livre-docência em Direito Internacional) - Faculdade de Direito, Universidade de São Paulo, São Paulo, 1967.

STRENGER, Irineu. Da autonomia da vontade em direito internacional privado. São Paulo: Revista dos Tribunais, 1968.

STRENGER, Irineu. Direito do comércio internacional e lex mercatoria. Pref. Fábio Konder Comparato. São Paulo: LTr, 1996.

STRENGER, Irineu. Direito internacional privado: parte geral, direito civil internacional, direito comercial internacional. 1. ed. São Paulo: Revista dos Tribunais, 1986.

STRENGER, Irineu. Direito internacional privado: parte geral, direito civil internacional, direito comercial internacional. 4. ed. aumentada e atualizada. São Paulo: LTr, 2000.

STRENGER, Irineu. La notion de lex mercatoria en droit du commerce international. Recueil des Cours de l'Académie de Droit International, Leinden/Boston, v. 227, p. 207-356, 1991.

STRENGER, Irineu. Mandado de injunção. Prefácio de J. Cretella Jr. Rio de Janeiro: Forense Universitária, 1988.

STRENGER, Irineu. Prefácio. In: CASELLA, Paulo Borba. Comunidade européia e seu ordenamento jurídico. 1. ed. São Paulo: LTr, 1994.

STRENGER, Irineu. Prefácio. In: CASELLA, Paulo Borba. Comunidade européia e seu ordenamento jurídico. 2. ed. São Paulo: LTr, 2002.

STRENGER, Irineu. Regime jurídico da reparação do dano em direito internacional privado. 1971. 275 p. Tese (Titular em Direito Internacional Privado) - Faculdade de Direito, Universidade de São Paulo, São Paulo, 1971. 
STRENGER, Irineu. Reparação do dano em direito internacional privado. Prefácio de Amílcar de Castro. São Paulo: Revista dos Tribunais, 1973.

STRENGER, Irineu. Temas de formação filosófica. São Paulo: Revista dos Tribunais, 1986. 158 p.

STRENGER, Irineu. Teoria geral do direito internacional privado. São Paulo: José Bushatsky, 1973.

TRIEPEL, Hermann. Les rapports entre le droit international et le droit international. Recueil des Cours de l'Académie de Droit International, Leinden/Boston, v. 1, p. 73-122, 1923.

VAMPRÉ, Spencer. Memórias para a história da Academia de São Paulo. 2. ed. Brasília: INL; Conselho Federal de Cultura, 1977. p. 427-429.

VERDROSS, Alfred. Règles générales du droit international de la paix. Recueil des Cours de l'Académie de Droit International, Leinden/Boston, v. 30, p. 271-518, 1929. p. 276-277.

VIDIGAL, Allan. Faculdade de Direito do Largo de São Francisco: USP 190 anos. Prefácio de José Rogério Cruz e Tucci. São Paulo: DBA., 2017.

VIOTTI, Dario Abranches. O Conselheiro Brotero. Brasília, DF: Thesaurus, 1998. (Coleção Itiquira).

VIOTTI, Dario Abranches. O Conselheiro José Maria de Avelar Brotero. Revista da Faculdade de Direito da Universidade de São Paulo, São Paulo, v. 69, n. 2, p. 255-272, jan./dez. 1974. 
